\title{
Exploring SSP land-use dynamics using the IMAGE model: Regional and gridded scenarios of land-use change and land-based climate change mitigation
}

\author{
Jonathan C. Doelman ${ }^{\mathrm{a}, *}$, Elke Stehfest ${ }^{\mathrm{a}}$, Andrzej Tabeau ${ }^{\mathrm{b}}$, Hans van Meijl ${ }^{\mathrm{b}}$, Luis Lassaletta ${ }^{\mathrm{a}}$, \\ David E.H.J. Gernaat ${ }^{\mathrm{a}, \mathrm{c}}$, Kathleen Hermans ${ }^{\mathrm{d}, \mathrm{e}}$, Mathijs Harmsen ${ }^{\mathrm{a}, \mathrm{c}}$, Vassilis Daioglou ${ }^{\mathrm{a}, \mathrm{c}}$, \\ Hester Biemans $^{\mathrm{f}}$, Sietske van der Sluis ${ }^{\mathrm{a}}$, Detlef P. van Vuuren ${ }^{\mathrm{a}, \mathrm{c}}$ \\ a PBL Netherlands Environmental Assessment Agency, The Hague, The Netherlands \\ ${ }^{\mathrm{b}}$ Wageningen Economic Research, Wageningen University \& Research, The Hague, The Netherlands \\ c Copernicus Institute for Sustainable Development, Utrecht University, The Netherlands \\ ${ }^{\mathrm{d}}$ UFZ - Helmholtz Centre for Environmental Research, Department Computational Landscape Ecology, Leipzig, Germany \\ e Laboratory of Geo-Information Science and Remote Sensing, Wageningen University \& Research, Wageningen, The Netherlands \\ ${ }^{\mathrm{f}}$ Environmental Research (Alterra), Wageningen University \& Research, Wageningen, The Netherlands
}

\section{A R T I C L E I N F O}

\section{Keywords:}

Shared Socio-economic Pathways (SSPs)

Integrated assessment

Land-use change

Climate change mitigation

Bioenergy

REDD

\begin{abstract}
A B S T R A C T
Projected increases in population, income and consumption rates are expected to lead to rising pressure on the land system. Ambitions to limit global warming to $2{ }^{\circ} \mathrm{C}$ or even $1.5{ }^{\circ} \mathrm{C}$ could also lead to additional pressures from land-based mitigation measures such as bioenergy production and afforestation. To investigate these dynamics, this paper describes five elaborations of the Shared Socio-economic Pathways (SSP) using the IMAGE 3.0 integrated assessment model framework to produce regional and gridded scenarios up to the year 2100 . Additionally, land-based climate change mitigation is modelled aiming for long-term mitigation targets including $1.5^{\circ} \mathrm{C}$. Results show diverging global trends in agricultural land in the baseline scenarios ranging from an expansion of nearly 826 Mha in SSP3 to a decrease of more than 305 Mha in SSP1 for the period 2010-2050. Key drivers are population growth, changes in food consumption, and agricultural efficiency. The largest changes take place in Sub-Saharan Africa in SSP3 and SSP4, predominantly due to high population growth. With low increases in agricultural efficiency this leads to expansion of agricultural land and reduced food security. Land use also plays a crucial role in ambitious mitigation scenarios. First, agricultural emissions could form a substantial component of emissions that cannot be fully mitigated. Second, bioenergy and reforestation are crucial to create net negative emissions reducing emissions in SSP2 in 2050 by $8.7 \mathrm{Gt} \mathrm{CO}_{2} / \mathrm{yr}$ and $1.9 \mathrm{Gt} \mathrm{CO}_{2} / \mathrm{yr}$, respectively $\left(1.5^{\circ} \mathrm{C}\right.$ scenario compared to baseline). This is achieved by expansion of bioenergy area (516 Mha in 2050) and reforestation. Expansion of agriculture for food production is reduced due to REDD policy (290 Mha in 2050) affecting food security especially in Sub-Saharan Africa indicating an important trade-off of land-based mitigation. This set of SSP land-use scenarios provides a comprehensive quantification of interacting trends in the land system, both socio-economic and biophysical. By providing high resolution data, the scenario output can improve interactions between climate research and impact studies.
\end{abstract}

\section{Introduction}

The land system plays a crucial role in human development, providing key products and ecosystem services such as food, fibre, shelter and freshwater (Foley et al., 2005). The demands that humanity places on the land system have increased substantially over the last century. As the global population increased to over 7 billion people, total land use increased from $13 \%$ of global land area in 1900 to $35 \%$ in 2000
(Klein Goldewijk et al., 2011). Moreover, less than 25\% of the world's ice-free area is still free from human influences (Ellis and Ramankutty, 2008). As the global population (KC and Lutz, 2017), income (Dellink et al., 2017) and food consumption (Alexandratos and Bruinsma, 2012; Popp et al., 2017) are expected to continue to increase, it is likely that human demands placed on the land system will continue to increase as well. A key question is what the increase in demand for products and ecosystem services implies for the sustainability of the land system (Erb

\footnotetext{
* Corresponding author at: PBL Netherlands Environmental Assessment Agency, Box 30314, 2500 GH, The Hague, The Netherlands.

E-mail address: jonathan.doelman@pbl.bl (J.C. Doelman).
} 
et al., 2016; Smith et al., 2010; Foley et al., 2011; Lambin and Meyfroidt, 2011).

Global land use plays an important role in climate change. Emissions from agriculture, forestry and other land use (AFOLU) are estimated to be responsible for around $24 \%$ of anthropogenic greenhouse gas (GHG) emissions in 2010 (Smith, 2013). $\mathrm{CO}_{2}$ emissions from land-use change and forestry have been more-or-less stable from 1970 to 2010 at approximately $5 \mathrm{Gt} \mathrm{CO}_{2} / \mathrm{yr}$, showing a tentative decrease from 2000 to 2010 while increasing again in the last five years (Quéré et al., 2016). $\mathrm{CH}_{4}$ and $\mathrm{N}_{2} \mathrm{O}$ emissions from land use have shown a continuous increase with growing crop and animal production: from around $3.7 \mathrm{Gt} \mathrm{CO}_{2} \mathrm{eq}$ and $1.3 \mathrm{Gt} \mathrm{CO}_{2} \mathrm{eq}$ in 1970 respectively, to $4.3 \mathrm{Gt}$ $\mathrm{CO}_{2} \mathrm{eq}$ and $2.1 \mathrm{Gt} \mathrm{CO}_{2} \mathrm{eq}$ in 2010 (JRC/PBL, 2012). These emissions are especially relevant for policies aiming to limit global mean temperature change to $2{ }^{\circ} \mathrm{C}$ or even $1.5^{\circ} \mathrm{C}$, as technical potential to reduce $\mathrm{CH}_{4}$ and $\mathrm{N}_{2} \mathrm{O}$ emissions is limited (Gernaat et al., 2015). The land system is also important in climate change mitigation policies as it provides the possibility to generate negative emissions through afforestation and bioenergy with carbon capture and storage (BECCS) that are crucial in ambitious mitigation scenarios (Van Vuuren et al., 2013).

Many key driving forces of the future land system are inherently uncertain, ranging from socio-economic variables such as population, wealth, human and livestock diets, waste and urbanization to biophysical parameters such as climate, yields, the carbon cycle and hydrological cycle. Their interactions determine what land-use futures might look like. In several earlier scenario studies, different land-use scenarios have been developed to quantify the possible consequences of different socio-economic development patterns (Popp et al., 2013; Smith et al., 2010; Strengers et al., 2004; Schmitz et al., 2014). The Shared Socioeconomic Pathway (SSP) scenario framework builds on this work by defining five scenarios that together describe a wide set of different socio-economic futures (O'Neill et al., 2017; Riahi et al., 2017). The SSPs can be combined with different long-term mitigation targets based on the Representative Concentration Pathways (RCP) (Van Vuuren et al., 2011) to produce a scenario matrix that allows assessment of different climate policy strategies (Van Vuuren et al., 2012).

Land-use scenarios are used for many applications, both in traditional climate research (Ciais et al., 2014; Jones et al., 2016) and beyond in studies on e.g. biodiversity (Alkemade et al., 2009), nutrient cycles (Beusen et al., 2015) and flood risks (Winsemius et al., 2013). Here, we present a consistent set of scenarios as developed with the IMAGE model (Stehfest et al., 2014). The IMAGE 3.0 model is a comprehensive integrated assessment model (IAM) that combines regional agro-economic, energy and climate policy modelling (26 regions) with land-use, dynamic vegetation and hydrological modelling on a geographic grid (5 and 30 arc-minute grid cells). This set-up allows the development of high resolution data, available online at regional ${ }^{1}$ and gridded $^{2}$ levels meeting the demand of different scientific communities.

In Van Vuuren et al. (2017), the overall elaboration of the SSP scenarios in IMAGE 3.0 was described. Here, we specifically focus on the land-use components of these scenarios. In doing so, the article adds to the existing literature on possible land-use trends for the SSPs. First, the article gives a detailed presentation of a set of scenarios developed with one IAM, thus providing a consistent set across SSPs and mitigation targets and providing the detail required to understand modelspecific land-use dynamics as presented before in multi-model analyses (Hurtt et al., 2011; Popp et al., 2016). Second, the article for the first time discusses high resolution land-use results of the SSPs. Third, the article presents spatially-explicit results of land-use dynamics of the IMAGE $1.5^{\circ} \mathrm{C}$ scenarios. We use the set of scenarios to answer the following questions: 1) What are potential land-use futures? 2) What are

\footnotetext{
${ }^{1}$ Regional data available for download: http://themasites.pbl.nl/models/image/index. php/Download

${ }^{2}$ Gridded data available for download: https://data.knmi.nl/datasets?q = PBL
}

geographic hotspots of change where large changes in the land system can occur? 3) What is the role of land use in climate change mitigation?

The paper start with a description of the IMAGE 3.0 framework with a focus on the land-use components of the model (Section 2.1), followed by a description of the SSP storylines and climate change mitigation targets (Section 2.2) and the implementation of the scenarios in IMAGE (Section 2.3). Subsequently, results of land-use dynamics in the baselines are presented on the global (Section 3.1) and (sub-)regional scale (Section 3.2), followed by results of the mitigation scenarios (Section 3.3) and the implications for greenhouse gas emissions (Section 3.4). Finally, conclusions, model uncertainties and effects on the results are discussed (Section 4).

\section{Methods}

\subsection{The IMAGE 3.0 model framework}

IMAGE $3.0^{3}$ is an integrated assessment modelling framework that simulates the interactions between human activities and the environment (Stehfest et al., 2014), to explore long-term global environmental change and policy options in the areas of climate, land and sustainable development. The framework comprises a number of sub-models describing land use, agricultural economy, the energy system, natural vegetation, hydrology, and the climate system (Supplementary information (SI) Fig. 2). In the description, we focus on the land-related components of IMAGE and their interactions (Figs. 1 and 2). The submodels operate at different spatial resolutions. The socio-economic components work at the level of 26 regions while the environmental components work at the grid level to take into account heterogeneities in environmental circumstances. Interaction between the models takes place through upscaling and downscaling algorithms. For example, crop productivity is modelled at the grid level and subsequently aggregated to the regional level for the exchange with the agricultural economy (MAGNET) and energy system (TIMER). Similarly, land use in IMAGELandManagement is represented at 5 arc-minute resolution, and aggregated to 30 arc-minute resolution for the data exchange with LPJmL. Next to differences in spatial resolution, sub-models are either hard- or soft-coupled. For example, IMAGE-LandManagement is hard-coupled to LPJmL which means that data is exchanged on an annual basis (see also Müller et al. (2016)). In contrast, IMAGE-LandManagement is softcoupled to TIMER through an iterative process of scenario data exchange. A sequence of data-exchange procedures ensures that relevant feedbacks represented in different sub-models are taken into account. A detailed description of all parameters exchanged between the various IMAGE sub-models is available ${ }^{3}$ (Stehfest et al., 2014).

IMAGE-LandManagement determines the area and location of cropland on a 5 arc-minute geographical grid required to fulfil the demand for production of 7 crop classes (temperate cereals, rice, maize, tropical cereals, pulses, roots and tubers, oil crops) calculated by MAGNET. The historical locations and areas of cropland and grazing land are based on the HYDE database (Klein Goldewijk et al., 2011) which is consistent with FAO statistics (FAOSTAT, 2013). For each region in each time step crop production is calculated using gridded potential yields from LPJmL, locations of cropland in the previous time step and a regional management factor (calibrated to historical yields from FAO and future yield trends according to MAGNET). If production is higher than demand, cropland is abandoned on the least productive locations. If production is lower than demand, cropland is expanded following an empirical allocation algorithm with four drivers: potential crop yield as modelled by LPJmL, accessibility from Nelson (2008), population density from the HYDE database (Klein Goldewijk et al., 2010), and terrain slope index from the Harmonized World Soil

\footnotetext{
${ }^{3}$ For more background info visit the online IMAGE documentation: http://themasites. pbl.nl/models/image/index.php/Welcome_to_IMAGE_3.0_Documentation
} 


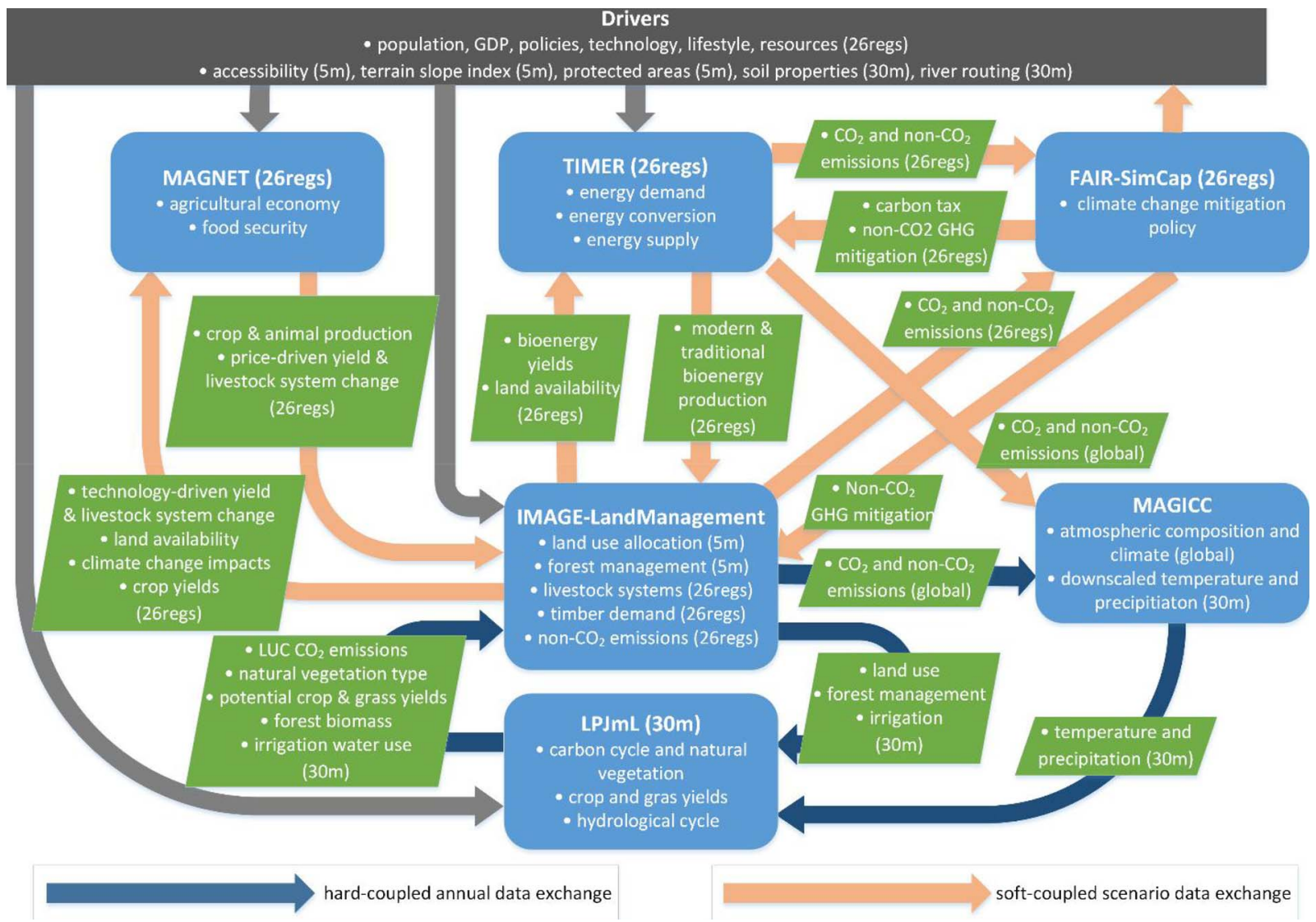

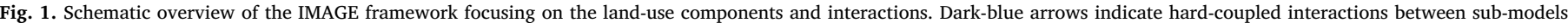

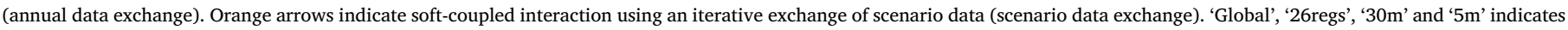

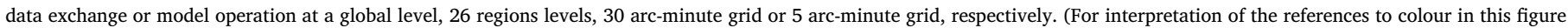
legend, the reader is referred to the web version of this article.)
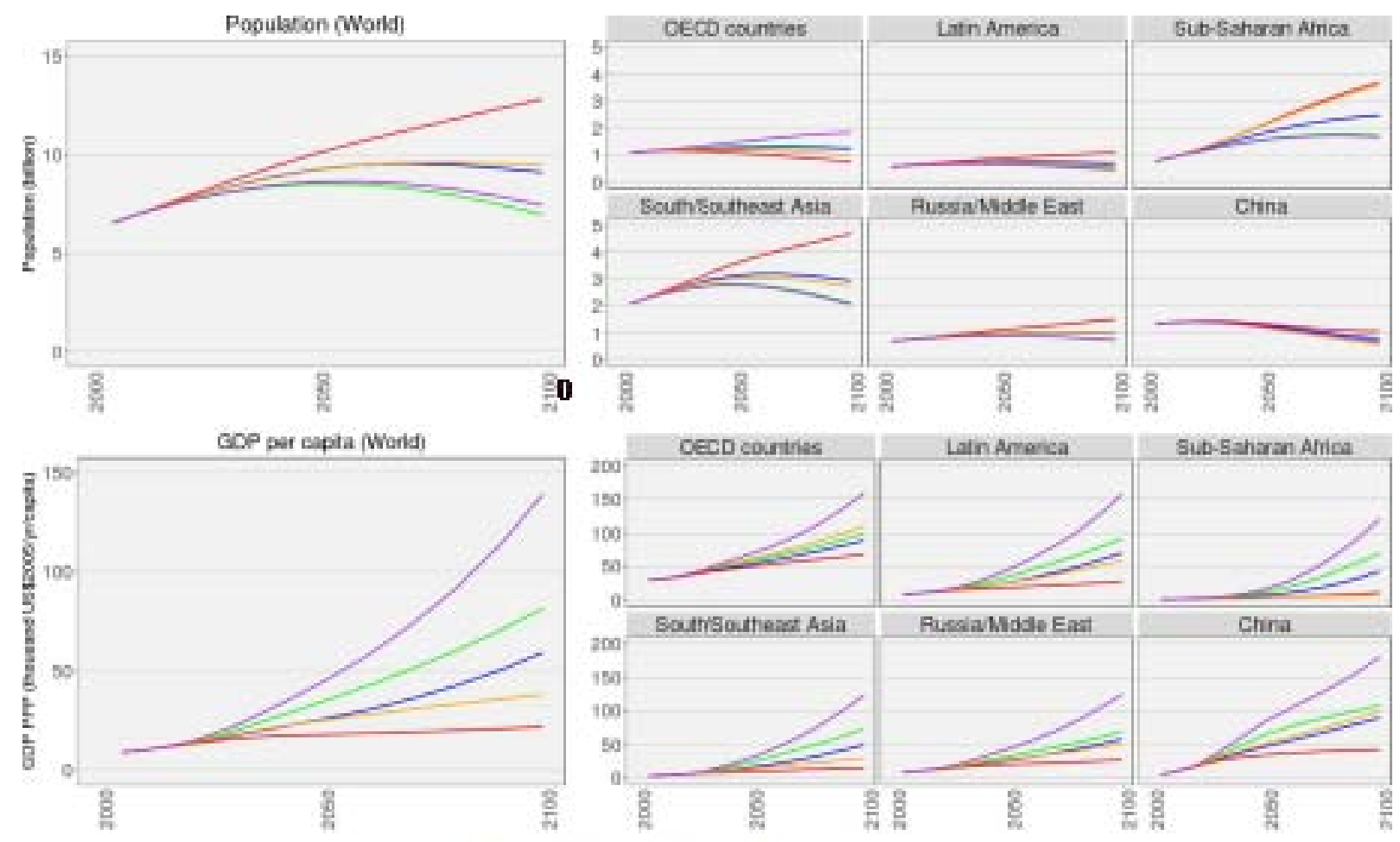

-SSP1-SSP2-SSP3 SSP4-SSP5

Fig. 2. Scenario-specific trajectories of population (KC and Lutz, 2017) and GDP per capita (Dellink et al., 2017) for the world and six aggregated regions (see also SI Table 2). 
Database (Fischer et al., 2008). The algorithm is based on regional multi-linear regression models fitted to explain current cropland and grazing land distribution. Next to land-use allocation, IMAGE-LandManagement includes a model for livestock production in five classes (beef, dairy, pigs, poultry, sheep and goats) for 26 regions in intensive and extensive systems taking into account large variations between regions in feed composition, feed efficiency, genetic animal productivity and age at slaughter (Bouwman et al., 2005). The livestock production module determines the amount of feed crops and grass required to fulfil demand for animal production as calculated by MAGNET. Expansion or abandonment of grazing land depends on demand for grass and follows the same allocation procedure as cropland. IMAGE-LandManagement also computes timber production in four forest management systems: clear cut, selective cut (conventional or reduced impact logging) and wood plantations.

MAGNET is a multi-regional, multi-sectoral, applied general equilibrium model (Woltjer and Kuiper, 2014) based on neo-classical microeconomic theory and it is an extension of the standard GTAP model (Hertel, 1997). The core of MAGNET is an input-output model, which links industries in value added chains from primary goods to final goods and services for consumption. Input and output prices are endogenously determined by the markets to achieve supply and demand equilibrium. The agricultural sector is represented in high detail compared to standard CGE models. Developments in productivity are driven by a combination of assumptions on autonomous technological change provided by IMAGE-LandManagement and by economic processes as modelled by MAGNET (i.e. substitution between production factors). Land is modelled as an explicit production factor described by a land supply curve, constructed with land availability data provided by IMAGE-LandManagement (Van Meijl et al., 2006). MAGNET provides information on agricultural demand, production, trade, and intensification or extensification of crop yields and livestock systems to IMAGE-LandManagement.

The dynamic vegetation model LPJmL (Müller et al., 2016) is an integral part of IMAGE (hard-coupled to IMAGE-LandManagement and MAGICC, annual data exchange) and simulates crop yields, grassland productivity, vegetation dynamics, and carbon and water cycles on a half degree geographic grid (Sitch et al., 2003; Bondeau et al., 2007). LPJmL is based on the concept of multiple plant functional types (PFTs) that are categorized according to biophysical characteristics. Both natural and crop PFTs are represented. Data on potential yields of the various crops and grasslands are provided to IMAGE-LandManagement. In return, IMAGE-LandManagement provides data on agricultural land use, irrigation and forest management, and MAGICC provides data on climate to LPJmL. Carbon and water cycle variables such as land-use change (LUC) $\mathrm{CO}_{2}$ emissions, carbon uptake and irrigation water use are returned to IMAGE-LandManagement.

The energy system is modelled for 12 primary energy carriers and 26 regions by the energy model TIMER (Van Vuuren, 2007). This is a simulation model that quantifies long-term trends in energy use using algorithms based on previous system states. Demand for bioenergy forms an important connection with IMAGE-LandManagement. Depending on bioenergy prices (determined by land supply, productivity of biomass for bioenergy, labour and capital costs, and learning dynamics) and other trends in the energy system (e.g. prices of competing energy sources) a certain demand for bioenergy is calculated by TIMER. The potential supply for bioenergy is calculated in IMAGE-LandManagement according to a set of sustainability rules: only abandoned agricultural lands and natural grass lands can be used, and bioenergy cannot directly compete with food (Hoogwijk et al., 2003). The potential yield of bioenergy biomass is calculated by LPJmL, and bioenergy land use is implemented in IMAGE-LandManagement. Preferably it is allocated on abandoned agricultural land. If no abandoned land is available, bioenergy is allocated on natural grasslands

Land-use $\mathrm{CO}_{2}$ emissions are calculated by grid-level process modelling of LUC and forestry in IMAGE-LandManagement and LPJmL.
Non- $\mathrm{CO}_{2}$ emissions $\left(\mathrm{CH}_{4}, \mathrm{~N}_{2} \mathrm{O}, \mathrm{CO}, \mathrm{NH}_{3}, \mathrm{NOx}, \mathrm{SOx}, \mathrm{NMVOC}, \mathrm{BC}, \mathrm{OC}\right)$ from land and agriculture are calculated from various activity data combined with emission factors that are calibrated to the historical period (SI Table 4). Together with emissions from energy and industry this determines total projected emissions. An implementation of the simple climate model MAGICC 6.0, is used to determine atmospheric concentrations, radiative forcing and global mean temperature change (Meinshausen et al., 2011). MAGICC emulates the behaviour of more complex climate models. Based on patterns of precipitation and temperature change in complex climate models, global mean temperature change and changes in precipitation are downscaled to a geographical grid at half degree resolution. Non- $\mathrm{CO}_{2}$ emissions are converted to $\mathrm{CO}_{2}$ eq for comparability using 100-year lifetime global warming potentials according to the IPCC (Solomon, 2007).

The climate policy model FAIR-SimCAP is used to determine global emission pathways with a long term climate target (Den Elzen et al., 2008). FAIR-SimCAP uses carbon prices and marginal abatement cost curves (MACs) representing costs of mitigation actions to determine a cost optimal emission pathway. MACs on $\mathrm{CO}_{2}$ mitigation in the energy sector are calculated by the TIMER model, including the use of BECCS. Mitigation potentials of non- $\mathrm{CO}_{2}$ GHGs are based on Lucas et al. (2007). The ambition level of REDD and reforestation of degraded forest areas is roughly calibrated to the carbon price using Kindermann et al. (2008).

\subsection{The SSP storylines and climate mitigation targets}

The SSP storylines describe the key developments in the SSPs for the baseline and the mitigation scenarios (O'neill et al., 2015). The storylines were used to derive demographic (KC and Lutz, 2017) and economic scenarios (Dellink et al., 2017)(see Table 1, Fig. 1). We earlier provided a description of the overall implementation of the SSP storylines in IMAGE (Van Vuuren et al., 2017). Here, we focus on the landuse components. Relevant storyline elements are supply, demand and trade of agricultural commodities, dietary preferences, agricultural efficiencies, policy on LUC, and climate change mitigation (see Table 1 for SSP storyline elements and SI Table 1 for IMAGE SSP assumptions).

The SSP storylines are combined with climate-change mitigation targets to assess the role of land use and LUC in climate change and to investigate the effect of climate change mitigation policy on land-use dynamics. Five long term targets are used to define the mitigation scenarios: $6.0 \mathrm{~W} / \mathrm{m}^{2}, 4.5 \mathrm{~W} / \mathrm{m}^{2}, 3.4 \mathrm{~W} / \mathrm{m}^{2}, 2.6 \mathrm{~W} / \mathrm{m}^{2}$ and $1.9 \mathrm{~W} / \mathrm{m}^{2}$. The first four scenarios correspond to the forcing targets of the initial set of RCP scenarios where $2.6 \mathrm{~W} / \mathrm{m}^{2}$ has a $66 \%$ likelihood to limit global warming to $2{ }^{\circ} \mathrm{C}$ (Van Vuuren et al., 2011). The $1.9 \mathrm{~W} / \mathrm{m}^{2}$ target has a $66 \%$ likelihood to limit global warming to $1.5{ }^{\circ} \mathrm{C}$ and has been added in response to the adoption of the Paris Agreement which aims "to limit the temperature increase to $1.5^{\circ} \mathrm{C}$ above pre-industrial levels" (UNFCC, 2015).

First, five baseline scenarios are developed to calculate how land use and climate change evolve in a world without mitigation policy. Subsequently, mitigation policies are introduced in each baseline scenario to achieve the defined targets. This leads to a set of 25 scenarios (SI Table 3). Some combinations are missing, for example in SSP1 the baseline radiative forcing is lower than the $6.0 \mathrm{~W} / \mathrm{m}^{2}$ target. In other scenarios the lower targets cannot be reached: $1.9 \mathrm{~W} / \mathrm{m}^{2}$ is infeasible for SSP3, SSP4 and SSP5, and $2.6 \mathrm{~W} / \mathrm{m}^{2}$ is infeasible for SSP3. Finally, a set of eight counterfactual scenarios are performed in which deployment of bioenergy is prevented in the energy and the land system is order to quantify the role of bioenergy in climate change mitigation.

\subsection{Scenario implementation}

In this section, the methodology through which the scenario-specific characteristics have been implemented in IMAGE are described (see also SI Table 1). In all scenarios climate feedbacks are taken into 
account in the natural system, e.g. through climate change effects on the carbon cycle. The climate impacts are calculated on the basis of greenhouse gas emissions of each scenario driven by both land-use and energy system trends. Effects of climate change on the socio-economic system are excluded, i.e. the effects of climate change on crop and grass yields and subsequently on agricultural economy are not taken into account. The standard approach in IMAGE does take climate change effects on the socio-economic system into account, however in the SSP design it was decided not to include these feedbacks. This design is implemented in the RCP (Van Vuuren et al., 2011) as well as the SSP process (Riahi et al., 2017) to facilitate consistent estimates of impacts, adaptation and vulnerability in follow-up research.

\subsubsection{Agricultural demand and trade}

Food consumption patterns form important drivers of land use (Stehfest et al., 2009). In our analysis food consumption is assumed to be a function of population and income as well as the SSP storyline. Based on the storyline, animal product consumption in SSP1 is assumed to be $30 \%$ lower than the consumption level projected by the MAGNET model without this preference shift. Conversely, in SSP3 and SSP5 animal product consumption is assumed to be $30 \%$ higher than projected without the preference shift. It is also assumed that losses in the food supply chain differ between the scenarios. Currently, food losses and waste throughout the chain range from e.g. $19 \%$ for cereals in SubSaharan Africa to $60 \%$ for roots and tubers in Northern America (Gustavsson et al., 2011). Reflecting this wide variation and consistent with the storylines, in SSP1 a 33\% reduction in losses in the food supply chain and at the household level is assumed related to increased environmental awareness. In SSP3 a 33\% increase in losses is assumed related to the growing share of inefficient supply chains in developing countries. In SSP5 also 33\% increase in food losses is assumed reflecting a consumption oriented society.

International trade is encouraged or discouraged by a wide variety of legislation and trade tariffs (Tokarick, 2006). To reflect these effects in the various scenarios, assumptions on import taxes are made based on the storylines: in SSP3 import taxes are assumed to increase by $10 \%$ due to regional rivalry. In contrast, all trade tariffs are assumed to be removed in SSP1 and SSP5 reflecting increased globalization. In SSP4, it is assumed that trade tariffs are removed in the high/middle-income regions, while import taxes are increased by $10 \%$ in low-income regions to represent inequality between world regions. In SSP2 trade tariffs and subsidies are assumed to stay at current levels.

\subsubsection{Land availability}

In IMAGE, some land is considered unavailable for agricultural production due to biophysical reasons such as low productivity $(<10 \%$ of maximum potential yield of the three most productive crop types from LPJmL), steep slopes ( $>45^{\circ}$ ), permafrost, ice cover (Fischer et al., 2008), or wetlands (Lehner and Döll, 2004). Land is also excluded for other reasons such as nature conservation in protected areas (based on WDPA (IUCN, 2015)) and urban areas (Klein Goldewijk et al., 2010). In addition, $10 \%$ of available land is excluded based on the assumption that subpixel heterogeneity and infrastructure makes part of the land unavailable for agricultural use (Verburg et al., 2009; Fritz et al., 2013). Lastly, also areas that have low probability to be converted to agriculture according to the IMAGE-LandManagement land-use allocation algorithm are excluded (Mandryk et al., 2015). This results in a global land availability for cropland and grazing land of 6717 Mha. This includes 4899 Mha that is already in use as cropland or grazing land, implying that 1819 Mha is available for possible land-use expansion (Fig. 2). Compared to the literature this is a medium to high estimate (Eitelberg et al., 2015).

Further scenario-specific restrictions on land availability are assumed in order to reflect storyline-driven efforts towards environmental conservation. In SSP1, SSP2 and SSP5, and in SSP4 medium/high-income regions, protected areas are expanded to achieve the Aichi 
biodiversity target in which $17 \%$ of terrestrial environments are protected (CBD, 2010). Protected areas are expanded in natural areas as computed by IMAGE-LandManagement in the year 2010, with a preference close to current protected areas according to the WDPA (IUCN, 2015). In addition, in each country $17 \%$ of each biome present is protected if possible. In SSP1 and in the high-income regions of SSP4 it is assumed that areas excluded from agricultural expansion are increased to cover $30 \%$ of the land. This is in line with the storyline on substantial land regulation, e.g. to ensure sustainable ecosystem services. In SSP3 and the low-income regions of SSP4, all available land can be converted to agriculture.

\subsubsection{Agricultural efficiencies}

Agricultural efficiencies are calculated on the basis of a projected base-level improvement in technology and management, in combination with price-driven yield increases leading to substitution between production factors as calculated endogenously in MAGNET. For SSP2, the overall regional crop yield changes are calibrated to the FAO Agricultural Outlook (Alexandratos and Bruinsma, 2012). It is assumed that $50 \%$ of the improvement is autonomous while the other $50 \%$ is price driven. For the other SSPs, the autonomous improvement has been derived from SSP2 using a correlation with GDP. As a result, advances in crop yields are high in SSP5 and SSP1, low in SSP3 and distributed across regions in SSP4.

Fertilizer application rates in SSP2 are based on the FAO Agricultural Outlook (Alexandratos and Bruinsma, 2012). It is assumed that in SSP1, SSP5 and high-income regions of SSP4, fertilizer efficiency improvement is $20 \%$ higher than SSP2 based on environmental concerns or technological improvements. Only in Sub-Saharan Africa where nutrient mining currently occurs (Lassaletta et al., 2014) does the application rate go up. In SSP3 and low-income regions of SSP4, $20 \%$ lower fertilizer efficiency improvements are assumed due to limited agricultural improvements.

Developments in the efficiency of livestock systems in SSP2 are also derived from the FAO Agricultural Outlook (Alexandratos and Bruinsma, 2012). Important characteristics are production performance and feed rations. In IMAGE-LandManagement a distinction is made between intensive (mixed and industrial) and extensive (pastoral) systems for ruminants. It is assumed that production in existing extensive systems remains stable. Additional demands for animal products are supplied by intensive systems (Bouwman et al., 2005). In SSP1 and SSP5, livestock system efficiencies are assumed to increase faster related to continued economic growth: less efficient regions experience $50 \%$ convergence with the most efficient regions. In contrast, in SSP3 the efficiency improvements are assumed to stagnate. In SSP4, high/ middle-income regions show continued efficiency improvements whereas low-income regions experience stagnation. The density of animals on grazing land is determined by MAGNET accounting for competing demands for land between grazing land and cropland.

\subsubsection{Irrigation}

Irrigated area projections in SSP2 are based on the FAO Agricultural Outlook (Alexandratos and Bruinsma, 2012): region specific growth rates of irrigated harvested area from 2005 to 2050 are applied to the 2005 areas equipped for irrigation. For 2050-2100 the 2030-2050 growth rate is assumed to continue. Irrigated area growth rates in SSP1 are assumed to be $50 \%$ lower than SSP2 because of low population growth and concerns about unsustainable water use. In contrast, in SSP3 growth rates are assumed to be 50\% higher than SSP2 related to high population growth. SSP5 is assumed to follow the same trend as SSP2, while in SSP4 high/medium/low income regions are assumed to follow the projections of SSP1/SSP2/SSP3, respectively.

Improvement of irrigation efficiency is implemented as a gradual closure of the gap between withdrawal and consumption. In SSP2, irrigation is assumed to depend on the relative increase in irrigated area as an indicator of regional investment in improved irrigation technology $(0.2 \% / \mathrm{yr}$ on new areas). In SSP1, the efficiency gap is assumed to decrease by $0.1 \% / \mathrm{yr}$ on all irrigated areas which is in line with the sustainability storyline and recommendations by the FAO to improve irrigation systems in order to reduce water footprints (Molden, 2007). The same efficiency change is assumed in SSP5 related to high economic growth and investments. In SSP3 on the other hand, efficiency is assumed to remain at 2005 levels. In SSP4 high/medium/low income regions are assumed to follow the projections of SSP1/SSP2/ SSP3, respectively.

\subsubsection{Urban areas}

Urban area development directly follows the approach of Klein Goldewijk et al. (2010). Urban population and population density are used to calculate urban area per country using a bell-shaped curve based on historical urban densities, which is subsequently downscaled on a 5 arc-minute grid.

\subsubsection{Forestry}

Global demand for timber is determined by the demand for fuelwood and industrial roundwood. Demand for fuelwood is modelled by the energy model TIMER, and is a function of access policies, poverty and the size of the rural population (Daioglou et al., 2012). Demand for industrial roundwood is determined by multiplying population with scenario-specific per capita demand. In SSP2 per capita demand increases by $5 \%$ up to 2100 . In SSP 1 global average per capita demand is reduced by $10 \%$ due to environmental awareness, while in SSP5 per capita demand increases by $40 \%$ due to high economic growth and consumption. In SSP3 and SSP4 per capita demands decrease by $10 \%$ and $5 \%$ respectively as the share of population living in poverty increases substantially. Production of timber and fuelwood can be done through clear cut, selective cut (reduced or high impacts) or wood plantations dependent on the storyline. In SSP3, we assume that the current systems persist, resulting in high impact selective logging in developing regions, while in SSP1 wood plantations and reduced impact logging are prevalent for biodiversity concerns.

The FAO's Forest Resource Assessment (FRA) provides detailed information on historical deforestation rates (FAO, 2015). Using historical data on expansion of agriculture from FAO, however, leads to considerably lower deforestation rates than reported by the FRA. In IMAGE it is therefore assumed that the differences are caused by additional reasons, e.g. unsustainable forestry preventing regrowth of natural forests, mining or illegal logging. To account for this, a historically calibrated rate of additional forest degradation is implemented. The trend is assumed to continue in the near future. In the environmentally aware world of SSP1 additional forest degradation is assumed to go to zero in 2040, while in the fragmented and underdeveloped world of SSP3 it continues until 2060.

\subsubsection{Land-based climate change mitigation}

In scenarios that aim to meet a specific climate target, three types of land-based climate change mitigation are implemented: bioenergy, REDD (avoided deforestation) and reforestation of degraded forest areas. Bioenergy demand is determined by the energy model TIMER based on bioenergy yield, the carbon price, dynamics in the energy system, and land availability following a food-first principle. REDD is implemented by protecting areas with high carbon stocks according to Ruesch and Gibbs (2008), i.e. by further limiting the land supply (Fig. 3). Three increasingly strict protection levels are defined at 200, 150 and 100 ton C/ha. Reforestation on degraded forest areas restores areas that have been degraded for reasons other than agriculture. Two levels of reforestation are defined: either half or all of the degraded forest areas are reforested.

The demand for bioenergy in climate change mitigation scenarios is linked to the carbon price required to reach the mitigation target in the IMAGE framework in competition with other mitigation options (discussed in more detail in van Vuuren et al. (2017)) . The levels of REDD 


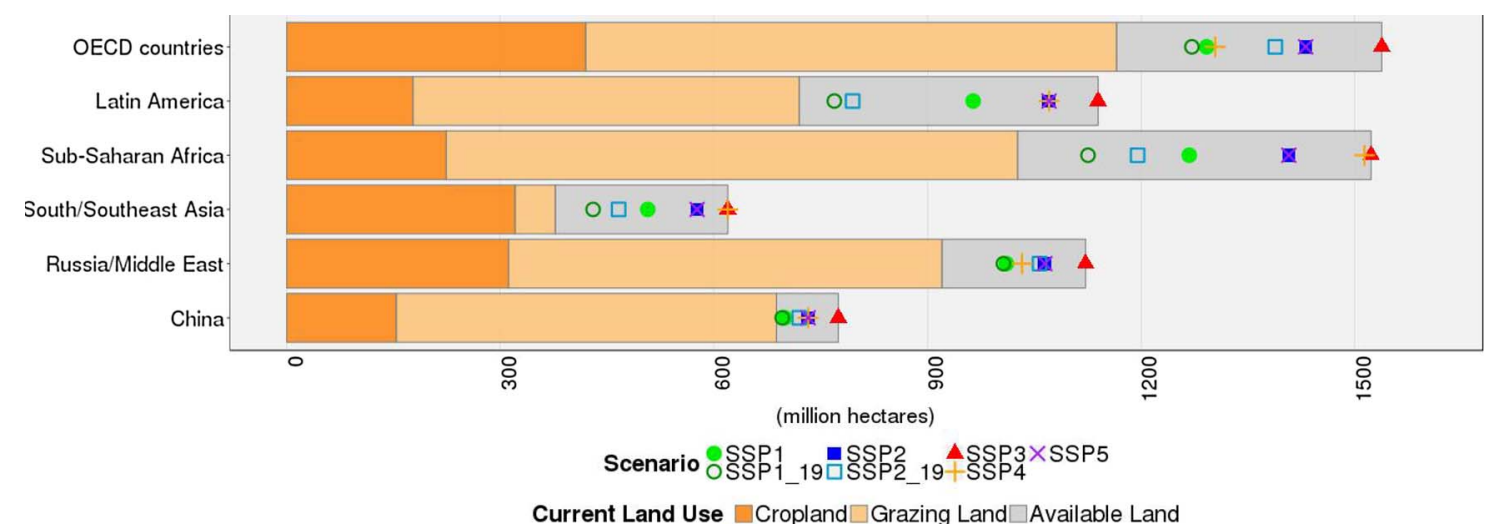

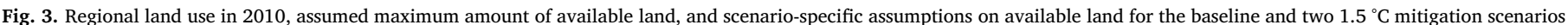
$\left(1.9 \mathrm{~W} / \mathrm{m}^{2}\right)$.

Table 2

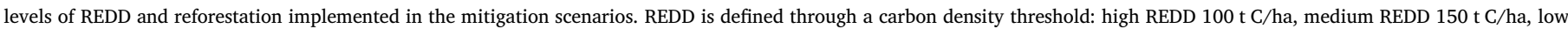

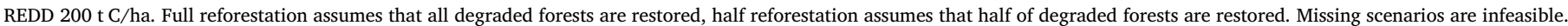

\begin{tabular}{|c|c|c|c|c|c|}
\hline $\begin{array}{l}\text { Climate target (W/ } \\
\mathrm{m}^{2} \text { ) }\end{array}$ & SSP1 & SSP2 & SSP3 & SSP4 & SSP5 \\
\hline 1.9 & High REDD, full reforestation & High REDD, full reforestation & - & - & - \\
\hline 2.6 & High REDD, full reforestation & $\begin{array}{l}\text { Medium REDD, full } \\
\text { reforestation }\end{array}$ & - & $\begin{array}{l}\text { Medium REDD, full } \\
\text { reforestation }\end{array}$ & High REDD, full reforestation \\
\hline 3.4 & $\begin{array}{l}\text { Medium REDD, full } \\
\text { reforestation }\end{array}$ & Low REDD, half reforestation & $\begin{array}{l}\text { No REDD, no } \\
\text { reforestation }\end{array}$ & Low REDD, half reforestation & $\begin{array}{l}\text { Medium REDD, full } \\
\text { reforestation }\end{array}$ \\
\hline 4.5 & Low REDD, half reforestation & No REDD, no reforestation & $\begin{array}{l}\text { No REDD, no } \\
\text { reforestation }\end{array}$ & No REDD, no reforestation & Low REDD, half reforestation \\
\hline 6.0 & & No REDD, no reforestation & $\begin{array}{l}\text { No REDD, no } \\
\text { reforestation }\end{array}$ & No REDD, no reforestation & No REDD, no reforestation \\
\hline
\end{tabular}

and reforestation are not linked to this price but roughly calibrated to abatement curves on avoided deforestation (Kindermann et al., 2008) (Table 2). Next to that, as land-based mitigation is assumed to be moderately successful in SSP2 and SSP4 and unsuccessful in SSP3, the levels of REDD and deforestation are relatively lower in those scenarios than would be expected if solely the carbon price is considered.

\section{Results}

\subsection{Global land-use dynamics in SSP baseline scenarios}

\subsubsection{Demand for agricultural products, bioenergy and wood}

Agricultural production (Fig. 4) is a dominant factor in observed LUC patterns. In all scenarios crop production for food and feed increases, ranging from $46 \%$ in SSP1 to $73 \%$ in SSP5 in $2010-2050$. For $2010-2100$, the increase ranges from $48 \%$ in SSP1 to $91 \%$ in SSP3. The production growth in all scenarios is predominantly driven by continued population and per capita income (GDP) growth up to 2050 (Fig. 2). In addition, high production in SSP3 and SSP5 is caused by dietary preference for animal products and high food losses and waste. The opposite characteristics are present in SSP1 leading to relatively low production growth. Production in 2050 in SSP5 is higher than in SSP3, even though population is substantially lower (8.6 and 10 billion resp.). The difference is caused by high levels of consumption driven by high per capita income increase in SSP5, as opposed to a large share of the population living in poverty in SSP3 with limited increases in percapita consumption. Change in grass production ranges from $-13 \%$ in SSP1 to $50 \%$ in SSP3 in $2010-2050$, and from $-35 \%$ in SSP1 to $89 \%$ in SSP3 in 2010-2100. The large variation results from differences in dietary preference for animal products and from increased efficiency in livestock production systems. The latter involves substitution in the feed composition of livestock with larger shares of feed crops relative to grass resulting in lower grass production and higher crop production in
SSP1 and SSP5. As a consequence of this, land abandonment in SSP1 mostly occurs on grazing land areas (Fig. 6 and SI Fig. 4d). This is less so the case in SSP5 due to higher animal product consumption and less incentive to abandon agricultural land for ecosystem restoration.

Production of biomass for bioenergy increases in all scenarios as it becomes a standard component of the energy mix, up to $4.0 \mathrm{Gt} / \mathrm{yr}$ in SSP1 in 2100. Demand for wood production decreases by $23 \%$ in SSP1 in 2010-2100, mostly due to specific policies focused on access to modern energy and reduced poverty leading to lower shares of traditional fuel such as fuel wood and charcoal. In contrast, wood production increases by $46 \%$ in SSP3 in 2010-2100 due to population growth leading to high timber demand and a large poor population creating high demand for traditional fuels.

\subsubsection{Agricultural efficiency}

Next to production, agricultural efficiency is an important factor determining the amount of land required to meet demand for agricultural products. Trends in globally averaged cereal yields show an overall increase in the productivity of cropping systems (Fig. 5). In SSP1 and SSP2 yields increase $50 \%$ from $3.2 \mathrm{t} /$ ha today to $4.8 \mathrm{t} / \mathrm{ha}$ in 2100 . In SSP5, yields increase up to $5.2 \mathrm{t} / \mathrm{ha}$. In SSP3 and SSP4, increases are slightly lower with yields going up $41 \%$ to $4.5 \mathrm{t} /$ ha in 2100 .

Livestock system efficiencies determine the amount of feed and grass required to produce animal products. Efficiencies (expressed as dry matter animal product output as a percentage of total dry matter feed and grass input) differ greatly between types of animal products with $10.3 \%$ for pigs and poultry, $7.9 \%$ for dairy cattle and $1.1 \%$ for beef cattle in 2010 (Fig. 5). From 2010-2100, especially SSP1 and SSP5 show large improvements, up to $12 \%$ for dairy cattle. In SSP3 and SSP4 however a reduction in efficiency down to $6.2 \%$ and $6.7 \%$, respectively, takes place. This results from low technological improvements and large production increases in areas with low efficiency, most notably Sub-Saharan Africa. 

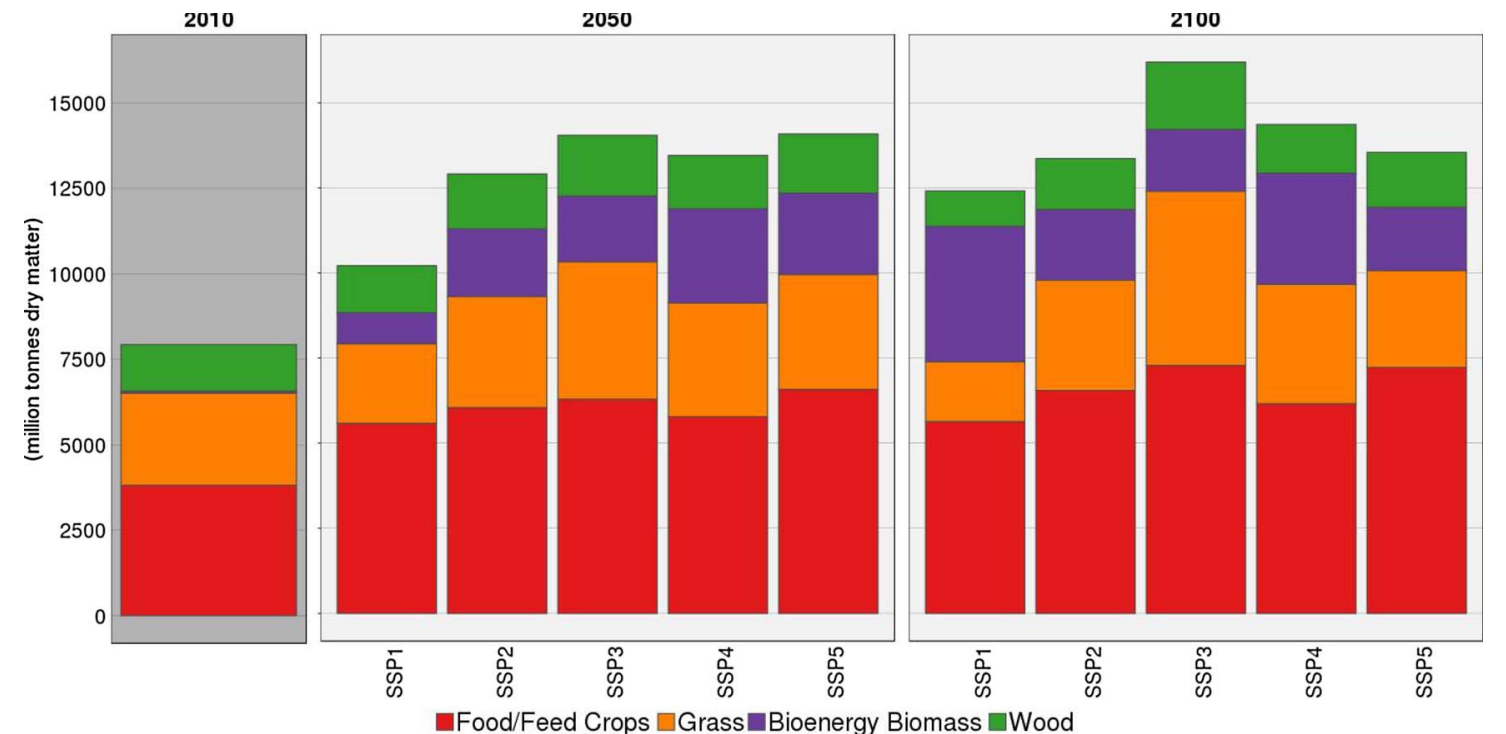

Fig. 4. Global production of food/feed crops, grass for livestock, biomass for bioenergy and wood for timber and fuel in 2010 , 2050 and 2100 in five baseline scenarios.

\subsubsection{Land-use change}

LUC varies substantially between the SSP scenarios (Fig. 6, Fig. 10). SSP3 shows the largest global increase in total cropland and grazing land amounting to 826 Mha for the period 2010-2050, after which it continues at a slower pace to a total increase of 1011 Mha for 2010-2100. In contrast, SSP1 shows a decrease of 305 Mha in 2010-2050 and 682 Mha in 2010-2100. For SSP2, SSP4 and SSP5, cropland and grazing land increases by $424 \mathrm{Mha}$, $459 \mathrm{Mha}$ and 655 Mha respectively in 2010-2050. After 2050, cropland and grazing land levels out resulting in a total increase of 412 Mha in SSP2, 423 Mha in SSP4 and 510 Mha in SSP5 for the period 2010-2100.

Changes in forest area are mostly driven by changes in agricultural land. In addition, forestry and additional forest degradation have a substantial impact when forest is assumed not to regenerate after timber harvesting. This results in a large decrease of 529 Mha in forest area compared to today in SSP3 in 2010-2100. In SSP1 a large increase of 296 Mha takes place in 2010-2100 as natural forest regrowth occurs on abandoned agricultural land, most notably in northern and eastern Europe, the eastern USA and eastern China (see SI Fig. 4f).

The increase in irrigated cropland in SSP2 is 59 Mha in 2010-2100 representing $27 \%$ of total cropland increase, indicating investment in existing cropland to achieve higher yields. This is also evident in SSP1 where irrigated cropland increases by 24 Mha even though total cropland decreases. In SSP3 on the other hand, irrigated cropland represents only $16 \%$ of total cropland increase in $2010-2100$ as cropland expansion mostly takes place in poor regions. Biomass plantation area for bioenergy is high in SSP1 after 2050 reaching 162 Mha in 2100 due to efforts to move away from a fossil-fuel based energy system. In SSP4, bioenergy area increases quickly due to self-sufficiency concerns up to 172 Mha in 2050.

Increases in built-up area range from 49 Mha in SSP3 to 74 Mha in SSP5 in 2010-2100. These estimates depend on population growth and rates of urbanization (Jiang and O'neill, 2017). This explains low increases in SSP3, because even though this scenario shows high
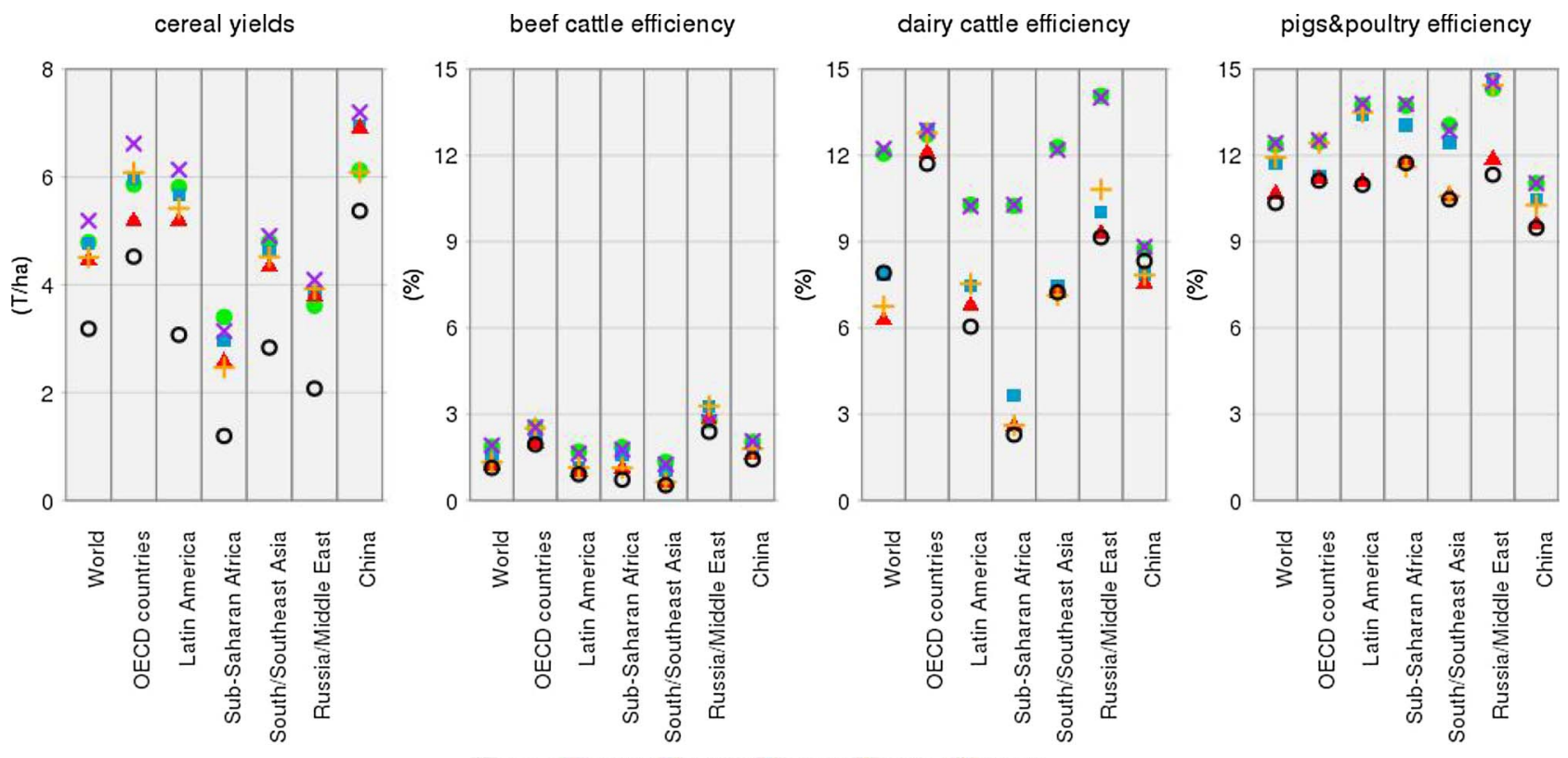

O 2010 -SSP $1=S S P 2 * S S P 3+S S P 4 \times S S P 5$

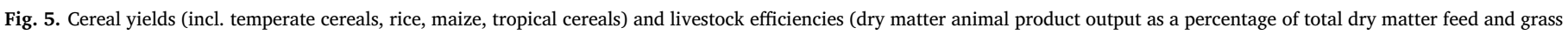
input for beef, dairy, and pigs and poultry respectively) in 2010 and 2100 for five baseline scenarios. 

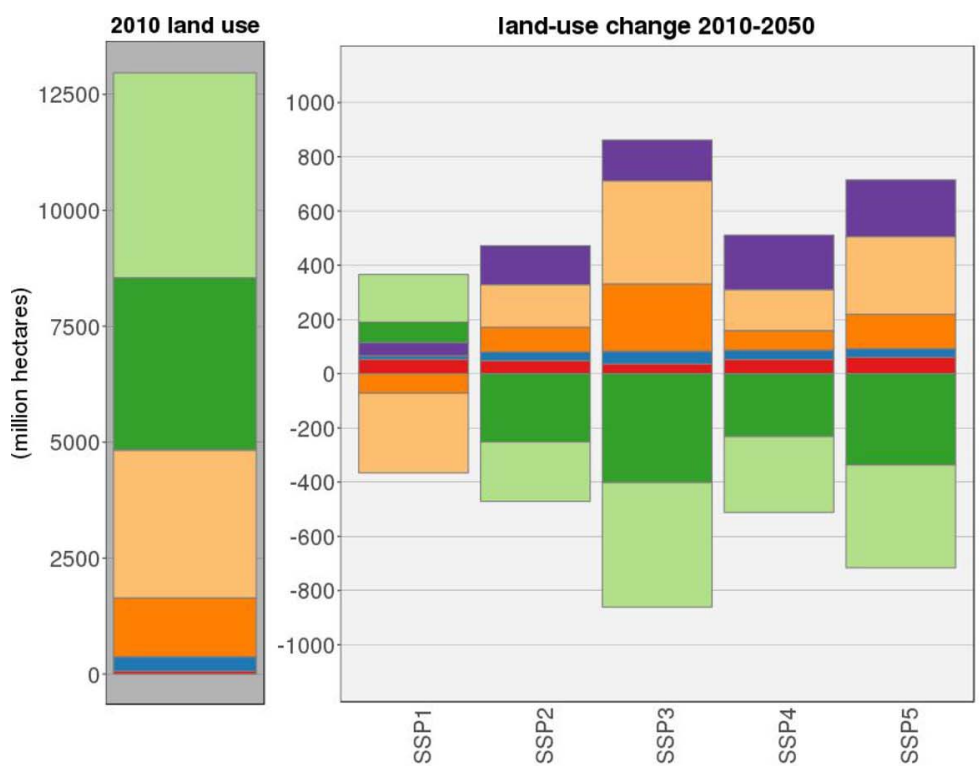

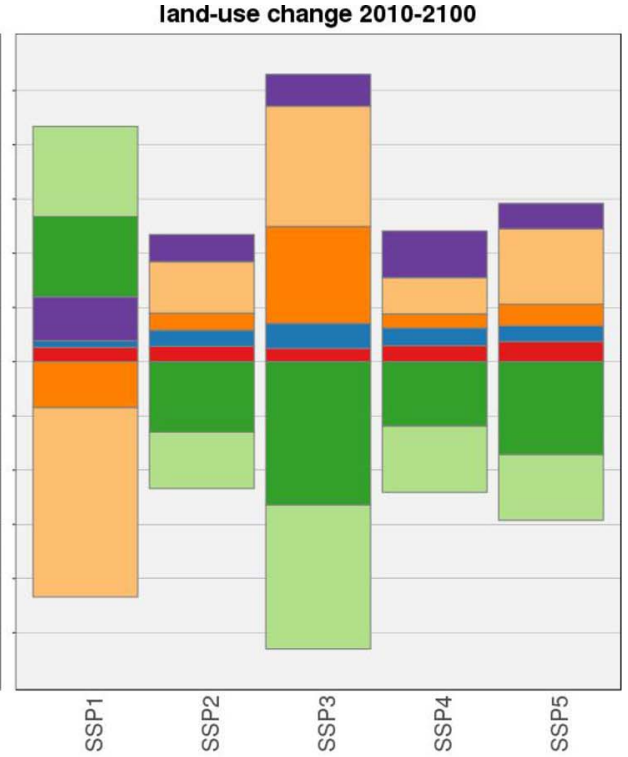

—Built-up Irrigated Crops $\square$ Rainfed Crops $\square$ Grazing Land $\square$ Bioenergy Plantations $\square$ Forest $\square$ Other Land

Fig. 6. Global land use in 2010, and global LUC for 2010-2050 and 2010-2100 for seven land-use classes in five baseline scenarios. Degraded forests are classified as other land.

population growth, levels of urbanization are low. On the other extreme, while global population in SSP5 is going down by the end of the century, built-up areas grow fast as almost the entire population urbanizes.

\subsubsection{Food security}

Globally averaged per capita food available for consumption increases in all scenarios (Fig. 7). SSP3 shows an increase of 3\% going from $2891 \mathrm{kcal} / \mathrm{cap} /$ day today to $2966 \mathrm{kcal} / \mathrm{cap} /$ day in $2100 \mathrm{in}$ dicating limited improvements in food security. In contrast, SSP5 shows an increase of $20 \%$ going to $3466 \mathrm{kcal} / \mathrm{cap} /$ day in 2100 . Food available for consumption is substantially lower in SSP1 compared to SSP5, even though per capita GDP (an important determinant of food availability) is high in both SSP1 and SSP5 (Fig. 2). This is due to lower levels of food losses and lower income elasticity representing a less consumption oriented society (see SI Table 1).

Variations in globally averaged food prices are large. In SSP1 a 58\% decrease in prices occurs, while in SSP3 prices increase by $251 \%$ (Fig. 7). These differences are in part determined by developments in agricultural efficiency and overall demand. For example, in SSP1 agricultural and supply chain efficiency increases substantially, while the increase in demand for agricultural commodities is relatively low. This results in a reduction of food prices. This is the opposite of SSP3, where low increases in agricultural efficiency, an inefficient food supply
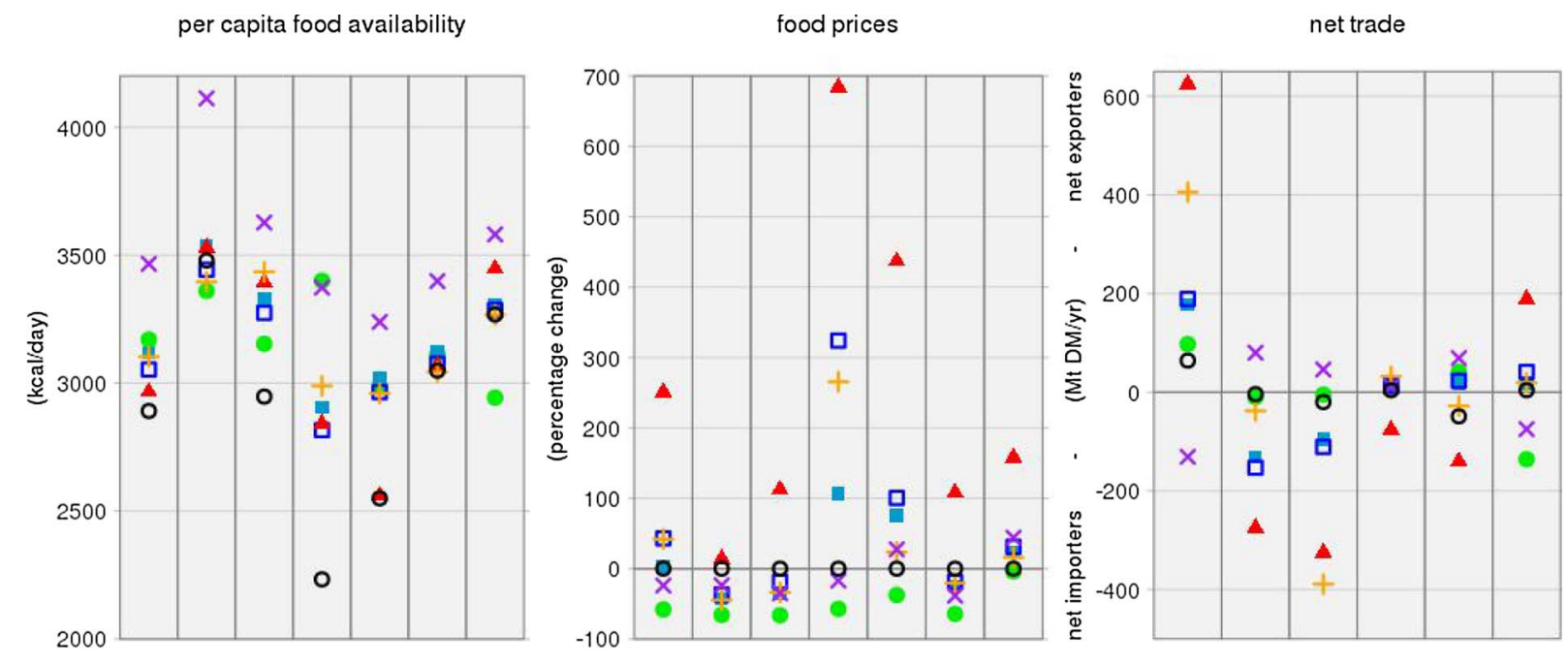

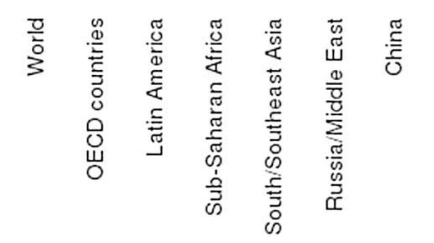

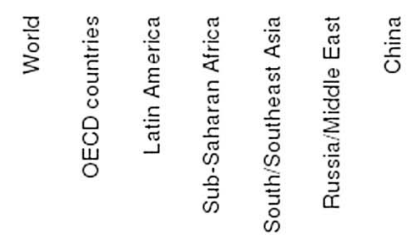

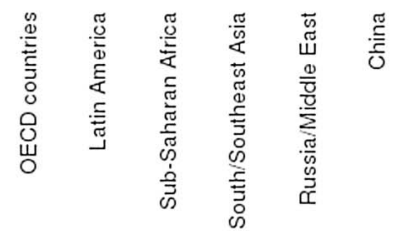

\footnotetext{
O 2010 SSP1 $\approx$ SSP2 $\square$ SSP2-1.9 4 SSP3 + SSP $4 \times$ SSP5
}

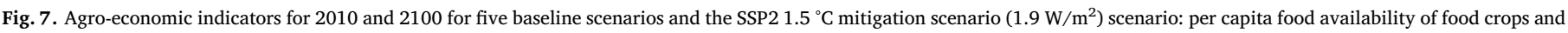
animal products in $\mathrm{kcal} / \mathrm{cap} /$ day, changes in average food prices, and net trade between the regions. 


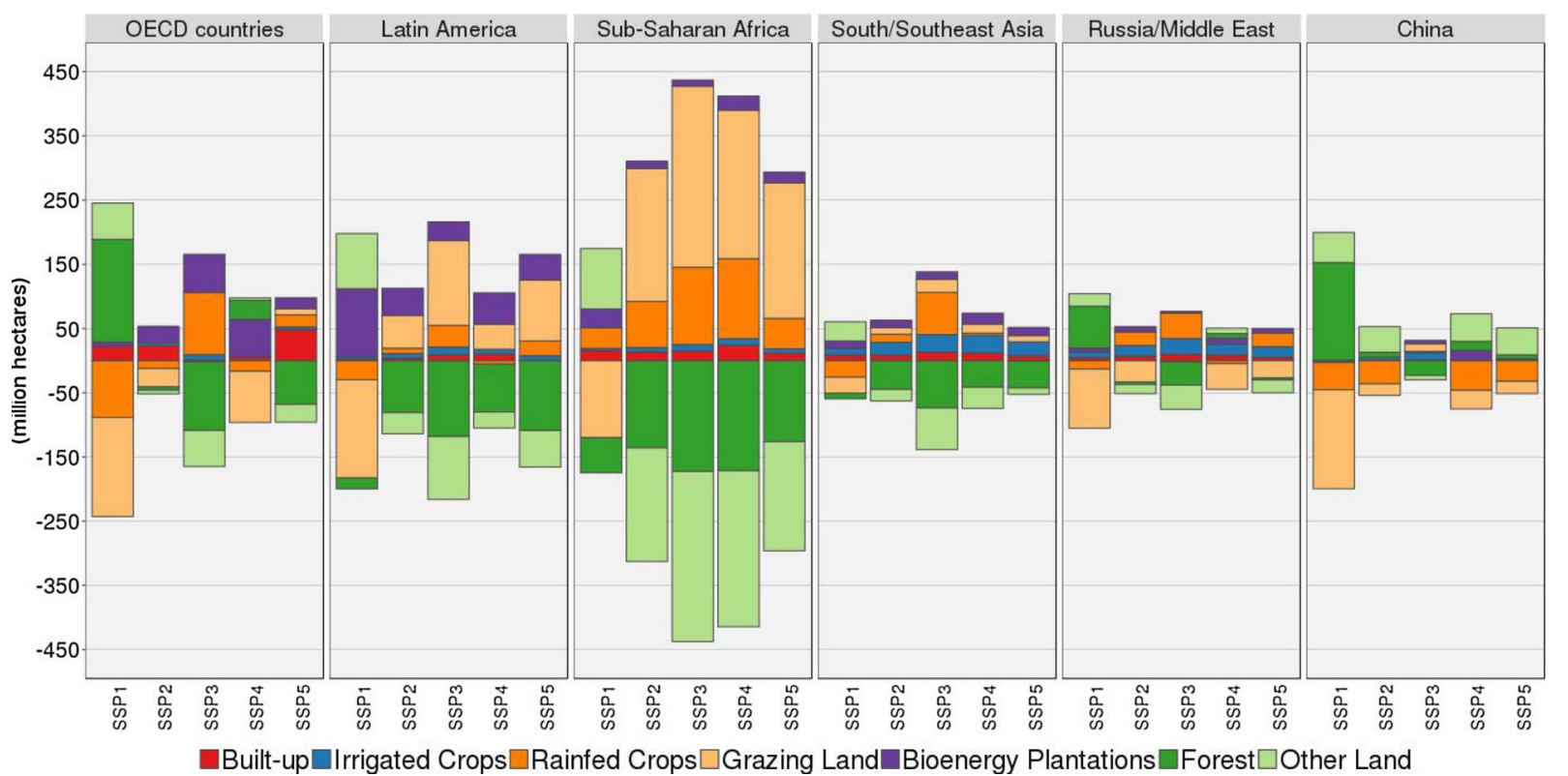

Fig. 8. Regional LUC for 2010-2100 for seven land-use classes in five baseline scenarios. Degraded forests are classified as other land.

chain and large increases in demand generate high food prices.

\subsection{Regional land-use dynamics in SSP reference scenarios}

The OECD countries (excl. Turkey, Mexico, Chile) show a decrease in agricultural land in SSP1, SSP2 and SSP4 in 2010-2100, up to 236 Mha in SSP1 (Fig. 8). The reduction mostly happens on grazing land, predominantly due to intensification in the livestock sector (e.g. in the eastern USA, SI Fig. 4d). In SSP3 a substantial increase of 163 Mha takes place, partly in response to high land pressure in other regions. In addition, although agricultural efficiency is already relatively high in the OECD countries, a continued increase is projected with cereal yields rising from $4.5 \mathrm{t} /$ ha to $6.0 \mathrm{t} / \mathrm{ha}$ in SSP2 creating higher crop production on similar land areas. As per capita food availability increases only slightly in most scenarios (Fig. 7) and population mostly decreases (Fig. 2) this results in a production surplus that is traded with other regions to make up for production shortages elsewhere: in SSP2 net export increases from $64 \mathrm{Mt}$ in 2010 to $178 \mathrm{Mt}$ in 2100.

Projected change in agricultural area in Latin America ranges from a reduction of 73 Mha in SSP1 to an increase of 207 Mha in SSP3 in
2010-2100. Per capita food availability increases in all scenarios resulting in increased production (Fig. 9). In SSP1, the livestock sector intensifies substantially, and food losses and dietary preferences for animal products are reduced, leading to abandonment of grazing land. Abandonment takes place in relatively productive areas (predominantly north-western Brazil, SI Fig. 4d) leading to high potential for bioenergy production. In the other SSPs higher demand is mostly met by increases in agricultural land along the arc of deforestation in Brazil and the Gran Chaco region in Bolivia, Argentina and Paraguay (Fig. 10). In contrast, in Central America possibilities for agricultural expansion are limited leading to import dependency.

Sub-Saharan Africa experiences the most extreme LUC of all regions in the various scenarios. SSP3 and SSP4 show an increase in agricultural area from 1015 Mha in 2010 to 1439 Mha and 1406 Mha respectively in 2100. Most expansion occurs on the rims of the Congo basin which is severely encroached, and smaller natural areas still left in Western Africa are all converted (Fig. 10). Only SSP1 shows a decrease of grazing land, though cropland is still expanding. A key driver is the growth of population. Despite the large expansion of cropland and grazing land, agricultural demand cannot be fulfilled within the region

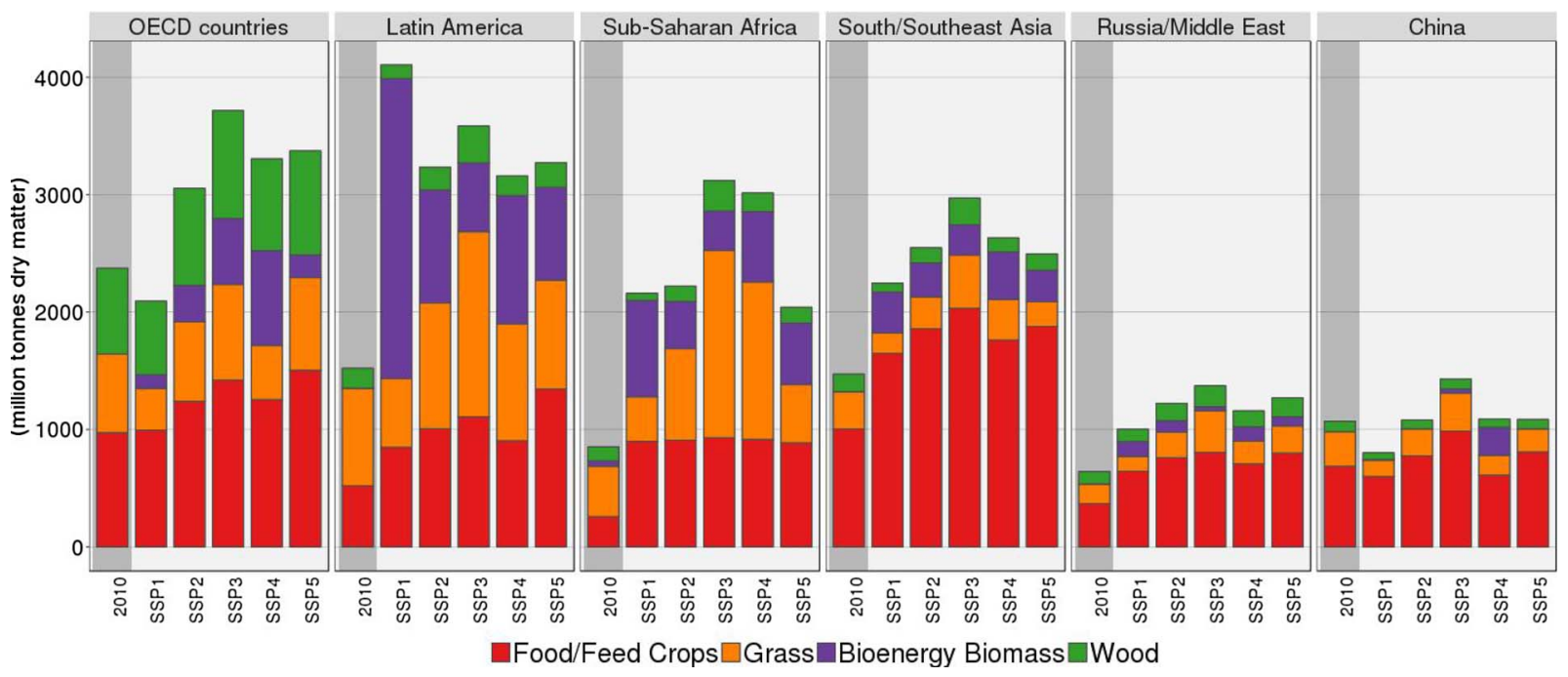

Fig. 9. Regional agricultural production in 2010 and 2100 for five baseline scenarios. 

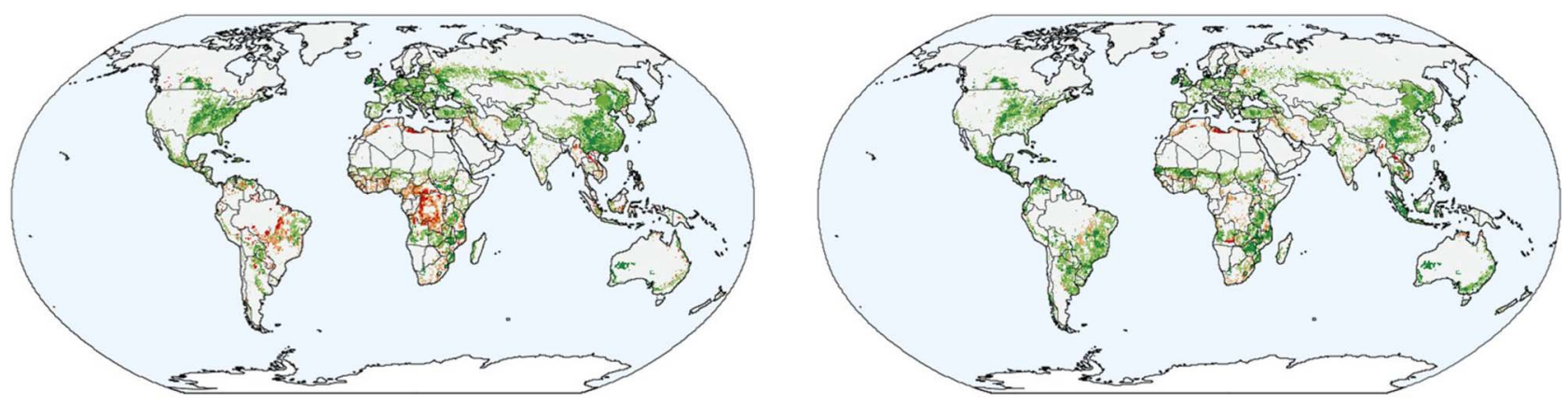

$5 \mathrm{SP}_{2}$

$\mathrm{SSP}_{2}-1.9$
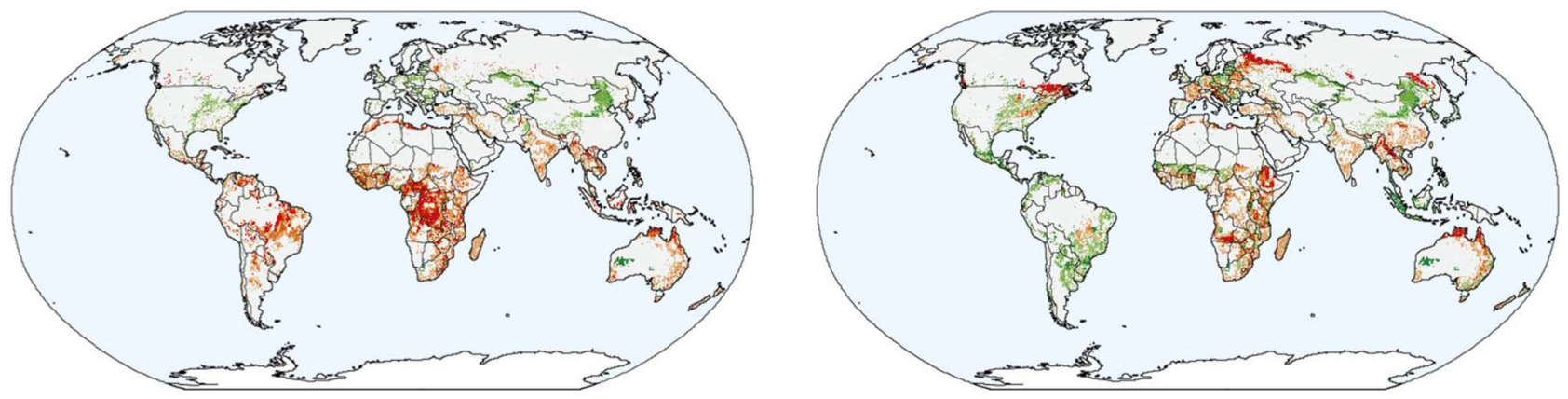

$\mathrm{SSP}_{3}$

$\mathrm{SSP}_{4}$
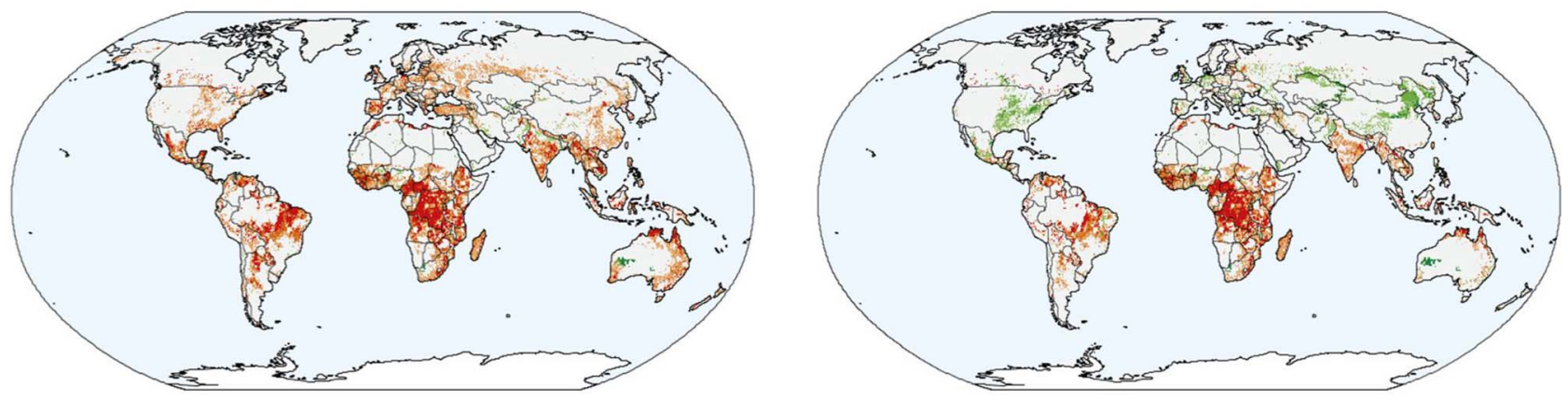

$5 \mathrm{SP}_{5}$

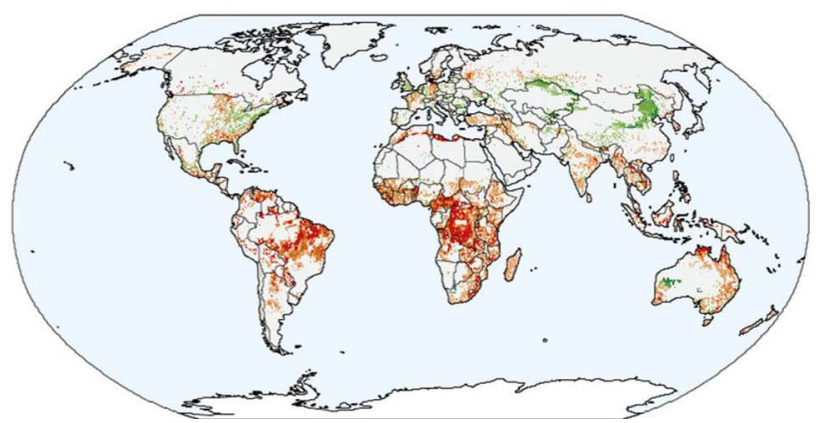

Deforestation and conversion of other natural land (\% change per gridcell)

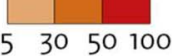

No or small change (less than $5 \%$ )

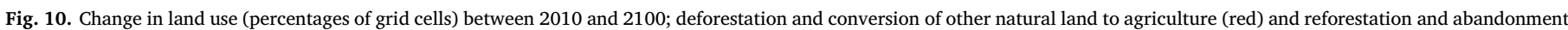

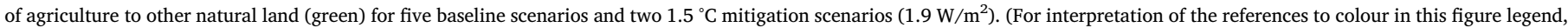
the reader is referred to the web version of this article.)

requiring high levels of net import from other regions. In SSP4, $389 \mathrm{Mt}$ in food commodities are imported compared to a regional crop production of $930 \mathrm{Mt}$. This implies an increasing dependency of Sub-Saharan Africa on food imports which might reduce food security. This is also illustrated by food prices which increase by $266 \%$ in SSP 4 and $684 \%$ in SSP3.

Agricultural land in South/Southeast Asia changes relatively little in 2010-2100 ranging from a reduction of 29 Mha in SSP1 to an increase 
of 125 Mha in SSP3, even though population increases substantially by 2100. This is partially due to low animal product consumption and especially low beef consumption for cultural reasons resulting in low demand for grass which is a major cause for LUC in other regions. On the other hand, crop production doubles to $2033 \mathrm{Mt}$ in SSP2. The limited effect on cropland is due to India which is a dominant country in South/Southeast Asia that has little potential for agricultural expansion. As a consequence, intensification is high in all scenarios leading to $53-73 \%$ higher yields. On the other hand, the effects on food security in SSP3 are large as food prices increase by $437 \%$ and food availability does not improve in the aggregated region. Food availability even deteriorates in India from $2493 \mathrm{kcal} / \mathrm{cap} /$ day in 2010 to $2357 \mathrm{kcal} / \mathrm{cap} /$ day in 2100.

The Russia/Middle East region (also including Northern Africa, Central Asia, Turkey, Ukraine and Belarus) show varying developments. In Russia and Central Asia grazing land is abandoned due to intensification in the livestock system. In addition, Ukraine and Russia increase their net export as yields increase on the large cropland areas that are currently not intensively used. On the other hand, in Northern Africa and the Middle East agricultural production on relatively unproductive land continues, even though these areas cannot fulfil demand of an increasing population. Consequently, these regions remain net importers of food crops.

Contrary to most other regions, China shows reductions in agricultural land in all scenarios. This is a consequence of the downward trends in the population projections in combination with substantial intensification in both crop yields and the livestock sector. Furthermore, even though meat consumption in China increases substantially this predominantly consists of pork as opposed to large shares of beef in OECD and Latin America. As pork is mostly fed with crops and residues this requires substantially less land thus reducing land demand in China. Therefore, afforestation trends that have been observed in recent years are projected to continue up to 152 Mha in SSP1 as a consequence of abandoning agricultural land.

\subsection{Impacts of land-based climate change mitigation on land dynamics}

Three types of land-based climate change mitigation are implemented: bioenergy, REDD (avoided deforestation) and reforestation of degraded forest areas. Implementation of large-scale bioenergy production (partly in combination with carbon capture and storage) is an essential mitigation strategy to reach ambitious climate targets (Daioglou, 2016). In mitigation scenarios with a $2.6 \mathrm{~W} / \mathrm{m}^{2}\left(2{ }^{\circ} \mathrm{C}\right)$ or a $1.9 \mathrm{~W} / \mathrm{m}^{2}\left(1.5^{\circ} \mathrm{C}\right)$ target this results in large increases in area used for bioenergy production in 2010-2100, ranging from 363 Mha in SSP1-2.6 and 225 Mha in SSP2-2.6, to 391 Mha in SSP1-1.9 and 414 Mha in SSP2-1.9 (Fig. 11). Almost all biomass for bioenergy is produced on plantations with fast-growing grass species or short-rotation coppice woody species that are suitable for second generation bioenergy. Allocation preferably takes place on abandoned agricultural land, most notably in central Europe, southern China and eastern USA, and on natural grasslands in central Brazil, eastern and southern Africa, and Northern Australia (SI Fig. 4e). The $1.9 \mathrm{~W} / \mathrm{m}^{2}$ target is very ambitious in an SSP2 world, requiring large-scale bioenergy deployment early in the century (516 Mha in 2010-2050) as well as using forest areas in temperate and boreal regions (notably Canada and Russia) with the assumption that replaced wood biomass is used for timber or bioenergy. Following the sustainability criteria applied in IMAGE, bioenergy production takes place on areas that are not required for food production, consequently not affecting any of the agro-economic indicators.

Areas that are addressed by REDD policy are located in regions with high density carbon stocks, predominantly the tropical areas. Therefore, land availability is reduced most in Latin America, SubSaharan Africa and South/Southeast Asia (Fig. 3). In SSP2-1.9 all forest with a carbon density higher than $100 \mathrm{t} \mathrm{C} /$ ha is protected leading to 311 Mha less cropland and grazing land compared to the baseline
(2010-2100)(Fig. 11). REDD has the largest effect on agricultural land use in Sub-Saharan Africa as this region is projected to have the highest agricultural land expansion in the baseline scenario (Fig. 8). In addition, the policy negatively affects food security shown by a reduction in food availability (from 2905 in SSP2 to $2816 \mathrm{kcal} / \mathrm{cap} /$ day in SSP2-1.9) and a sharp increase in food prices (306\% in SSP2-1.9 compared to $106 \%$ in SSP2)(Fig. 7). Also globally the effects of REDD are substantial: total agricultural production is reduced by $220 \mathrm{Mt}$ and food prices rise by $40 \%$ in SSP2-1.9 compared to SSP2 in 2100 .

REDD together with reforestation of degraded forest areas leads to substantial increases in forest area in the mitigation scenarios compared to the baseline scenarios: in 2100 forest area is respectively 220 Mha and 404 Mha higher than the baseline in SSP1-2.6 and in SSP2-2.6. In SSP2-1.9, the stringency of the mitigation target leads to more bioenergy production to achieve more negative emissions thus limiting the difference to 254 Mha compared to SSP2 in 2100.

\subsection{Greenhouse gas consequences of baseline and mitigation scenarios}

Emissions from agriculture and LUC are estimated to make up $20.6 \%$ of total emissions in 2010 (Fig. 12). With large increases in total emissions in the baselines (e.g. in SSP2 up to $74.8 \mathrm{Gt} \mathrm{CO}_{2} \mathrm{eq} / \mathrm{yr}$ in 2050 and $94.2 \mathrm{Gt} \mathrm{CO} 2 \mathrm{eq} / \mathrm{yr}$ in 2100) the share of agriculture and LUC emission reduces to $18.0 \%$ in 2050 and $8.1 \%$ in 2100 . This is even more extreme in SSP5 where total emissions in 2100 increase to $136.3 \mathrm{Gt}$ $\mathrm{CO}_{2} \mathrm{eq} / \mathrm{yr}$ reducing the share of agriculture and LUC to only $4.1 \%$ (SI Fig. 3). In contrast, in mitigation scenarios the relative share of agricultural emissions increases as emissions of energy, industry and LUC decrease dramatically. In 2100 agricultural emissions of $\mathrm{CH}_{4}$ and $\mathrm{N}_{2} \mathrm{O}$ are the largest source of net emissions in many ambitious mitigation scenarios (SSP1-2.6, SSP1-1.9, SSP2-2.6, SSP2-1.9) because of the limited reduction potential (Gernaat et al., 2015).

LUC $\mathrm{CO}_{2}$ emissions result from deforestation and reforestation. In 2050 all baseline scenarios except SSP1 are still a net source of $\mathrm{LUC} \mathrm{CO}_{2}$ emissions ranging from $5.0 \mathrm{Gt} \mathrm{CO}_{2} / \mathrm{yr}$ to $7.1 \mathrm{Gt} \mathrm{CO}_{2} / \mathrm{yr}$ in SSP5 and SSP3 respectively (SI Fig. 3). In 2100, only SSP3 continues to be a net source with $1.4 \mathrm{Gt} \mathrm{CO}_{2} / \mathrm{yr}$ whereas the other scenarios have near zero emissions (SSP2 and SSP4) or negative emissions up to $-2.4 \mathrm{Gt} \mathrm{CO}_{2} / \mathrm{yr}$ in SSP1 due to reductions in agricultural land. REDD and reforestation create more negative emissions due to faster reductions in LUC and due to reforestation of degraded forests. In SSP1-2.6 in 2050 emissions are $-1.6 \mathrm{Gt} \mathrm{CO}_{2} / \mathrm{yr}$ compared to $-0.2 \mathrm{Gt} \mathrm{CO}_{2} / \mathrm{yr}$ in the SSP1 baseline, while in SSP2-2.6 emissions are $2.6 \mathrm{Gt} \mathrm{CO}_{2} / \mathrm{yr}$ compared to $5.0 \mathrm{Gt} \mathrm{CO}_{2} /$ $\mathrm{yr}$ in the SSP2 baseline. From the $2.6 \mathrm{~W} / \mathrm{m}^{2}$ target to the $1.9 \mathrm{~W} / \mathrm{m}^{2}$ target LUC emissions are slightly higher again: $-0.6 \mathrm{Gt} \mathrm{CO}_{2} / \mathrm{yr}$ in SSP11.9 and $3.1 \mathrm{Gt} \mathrm{CO}_{2} / \mathrm{yr}$ in SSP2-1.9 in 2050. This is caused by increased land use for bioenergy production, resulting in reduced reforestation area and conversion of areas with relatively low carbon density to bioenergy production.

Approximately half of present-day $\mathrm{CH}_{4}$ land-use emissions are caused by the livestock sector. Other land-use $\mathrm{CH}_{4}$ sources are rice production, burning of biomass and agricultural waste. Projected emissions of the livestock sector depend on the total demand for animal products (particularly ruminants) and production efficiency. Projected emissions from biomass burning depend on LUC trends, and emissions from rice production and agricultural waste burning depend on crop production. Total projected emissions range from SSP3 with $6.1 \mathrm{Gt}$ $\mathrm{CO}_{2} \mathrm{eq} / \mathrm{yr}$ in 2050 and $6.9 \mathrm{Gt} \mathrm{CO}_{2} \mathrm{eq} / \mathrm{yr}$ in 2100 , to SSP1 with $3.7 \mathrm{Gt}$ $\mathrm{CO}_{2} \mathrm{eq} / \mathrm{yr}$ in 2050 and $3.2 \mathrm{Gt} \mathrm{CO}_{2} \mathrm{eq} / \mathrm{yr}$ in 2100 respectively. In the mitigation scenarios emissions are reduced dependent on the carbon price as there is substantial abatement potential: in SSP2-1.9 $\mathrm{CH}_{4}$ emissions are reduced by $40 \%$ in 2050 and $48 \%$ in 2100 compared to the SSP2 baseline. $\mathrm{CH}_{4}$ mitigation is already relatively high in 2050 because it is estimated to be a cheap measure compared to other mitigation options (Lucas et al., 2007) and because mitigation needs to be implemented very fast in case of a $1.9 \mathrm{w} / \mathrm{m}^{2}$ target. 

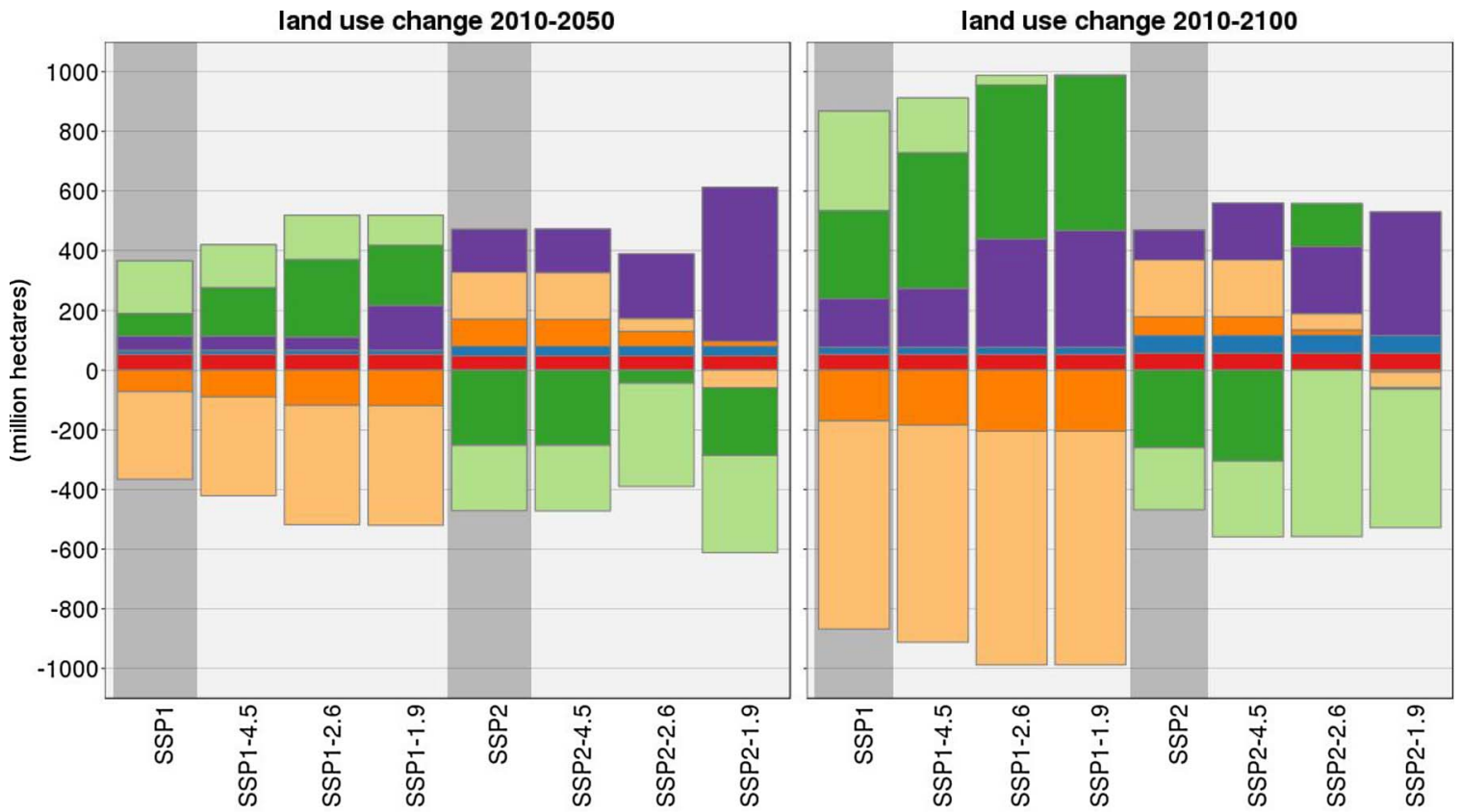

घBilt-up $\square$ Irrigated Crops $\square$ Rainfed Crops $\square$ Grazing Land $\square$ Bioenergy Plantations $\square$ Forest $\square$ Other Land

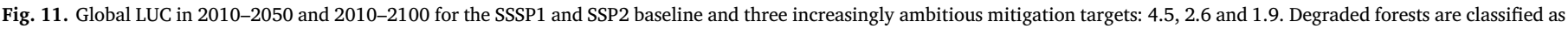
other land.
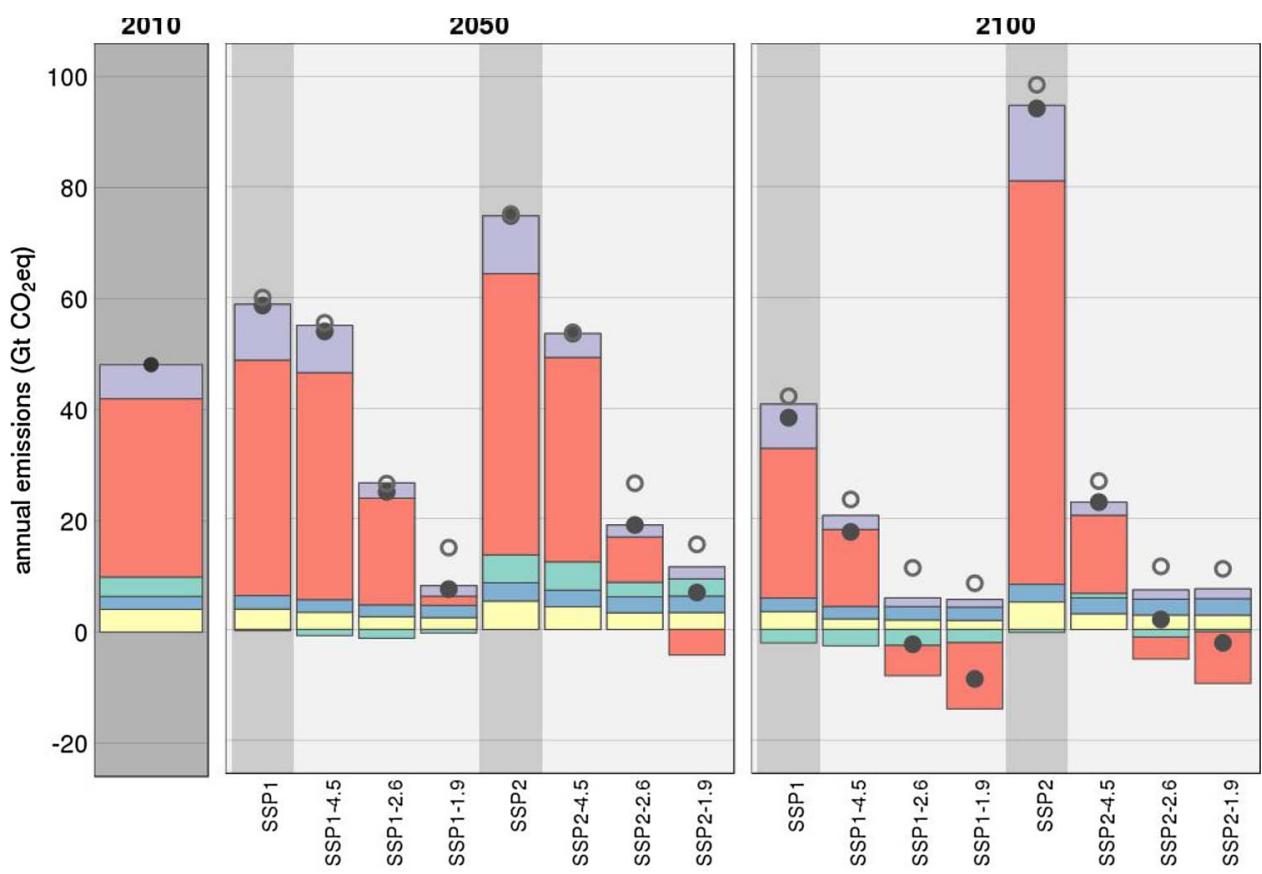

Fig. 12. GHG emissions in 2010, 2050 and 2100 from energy and industry, LUC including reforestation, and agriculture, net emissions and net emissions without mitigation due to bioenergy for two baseline scenarios and six mitigation scenarios.

net emissions $O$ net emissions excl. mitigation due to bioenergy use

Land-use emissions of $\mathrm{N}_{2} \mathrm{O}$ are predominantly determined by synthetic fertilizer application and livestock excretion. Emissions turn out highest in SSP3 with $4.4 \mathrm{Gt} \mathrm{CO}_{2} \mathrm{eq} / \mathrm{yr}$ in 2100 as synthetic fertilizer use is high due to inefficient fertilizer application in combination with high demand. Manure production is also high due to high demand and inefficient livestock systems requiring large numbers of animals. SSP1 has the lowest $\mathrm{N}_{2} \mathrm{O}$ emissions with $2.5 \mathrm{Gt} \mathrm{CO}_{2} \mathrm{eq} / \mathrm{yr}$ in 2100 due to lower demand and higher efficiencies in livestock systems and fertilizer application. The identified mitigation potentials are moderate with reductions of 9\% in 2050 and $7 \%$ in 2100 in SSP2-1.9 compared to the SSP2 baseline. Mitigation of $\mathrm{N}_{2} \mathrm{O}$ emissions is partially counteracted by higher levels of fertilizer use due to large-scale bioenergy production.

Mitigation through bioenergy by replacement of fossil fuels and BECCS are crucial components of ambitious mitigation scenarios. Preventing bioenergy use in the energy system causes increased emissions from fossil fuels. In addition, climate change mitigation is hampered as negative emissions from BECCS are made impossible. On the other hand, LUC emissions from the expansion of bioenergy plantations 
are reduced (SI Fig. 4e). A set of counterfactual scenarios in which deployment of bioenergy is prevented in the energy and the land system is used to quantify this effect. In the moderately ambitious mitigation scenarios SSP1-4.5 and SSP2-4.5 $\left(4.5 \mathrm{~W} / \mathrm{m}^{2} \approx 3{ }^{\circ} \mathrm{C}\right)$ bioenergy plays a moderate role with a difference of $5.9 \mathrm{Gt} \mathrm{CO}_{2} / \mathrm{yr}$ and $3.8 \mathrm{Gt} \mathrm{CO}_{2} / \mathrm{yr}$ respectively in 2100 (Fig. 12). However, in ambitious mitigation scenarios bioenergy is crucial to achieve negative emissions: in SSP1-2.6 and SSP2-2.6 bioenergy is responsible for an annual reduction of 13.8 $\mathrm{Gt} \mathrm{CO}_{2} / \mathrm{yr}$ and $9.6 \mathrm{Gt} \mathrm{CO}_{2} / \mathrm{yr}$ respectively in 2100 . Reductions in 2100 in SSP1-1.9 and SSP2-1.9 are even larger with $17.3 \mathrm{Gt} \mathrm{CO}_{2} / \mathrm{yr}$ and 13.4 $\mathrm{Gt} \mathrm{CO}_{2} / \mathrm{yr}$ respectively. An important characteristic of the $1.9 \mathrm{~W} / \mathrm{m}^{2}$ mitigation scenarios is that mitigation measures are implemented faster to be able to stay within the carbon budget: in 2050 reductions through bioenergy are $7.5 \mathrm{Gt} \mathrm{CO}_{2} / \mathrm{yr}$ in SSP1-1.9 compared to $1.4 \mathrm{Gt} \mathrm{CO}_{2} / \mathrm{yr}$ in SSP1-2.6, and $8.7 \mathrm{Gt} \mathrm{CO}_{2} / \mathrm{yr}$ in SSP2-1.9 compared to $7.6 \mathrm{Gt} \mathrm{CO}_{2} / \mathrm{yr}$ in SSP2-2.6. Generally, the role of bioenergy is larger in SSP1 than in SSP2 because of abandonment of grazing land which lowers biomass prices.

\section{Discussion and conclusions}

The results from the IMAGE SSP baseline scenarios show large variations in potential land-use futures. The most prominent LUC trends are in agricultural land use, ranging from large decreases in SSP1 to large increases in SSP3. The most striking hotspot of change is SubSaharan Africa, which shows the largest increases in agricultural land use of all regions in almost all scenarios causing large-scale deforestation. Key drivers are population growth, changes in food consumption depending on per capita GDP, and agricultural efficiency. In SubSaharan Africa these drivers lead to agricultural expansion and increasing import dependency in SSP3 and SSP4, while in SSP1 land use stabilizes and net trade is near zero. The difference in SSP3 and SSP4 compared to SSP1 indicates that major benefits can be gained in SubSaharan Africa from improved agricultural efficiency and reduced population growth, as also suggested by Billen et al. (2015). Large yield gaps exist in Sub-Saharan Africa with potential for increased production (Neumann et al., 2010; Van Ittersum et al., 2013; Mueller et al., 2012). Utilization of this potential could improve food security and at the same time reduce deforestation, although it is very uncertain if these intensification processes are feasible (Van Ittersum et al., 2016).

In contrast to Sub-Saharan Africa, China and the OECD countries show decreases in agricultural land use and increases in net export in nearly all scenarios. This is partly due to continued improvements in agricultural efficiencies, which is in line with historically observed trends. However, it is questioned if crop improvements can continue in the future because biological limits may have been reached (Grassini et al., 2013). If increases in agricultural efficiency stagnate in developing regions, reforestation on former agricultural land and net export of food could be negatively affected. A more detailed representation of the different components responsible for yield increases (Fischer et al., 2014) is required to improve long-term projections.

Indicators of food security discussed in this paper are food availability and food prices (indicative of food accessibility). Although this is a limited set that does not take into account differences between population groups within regions (FAO, 1996; Hasegawa et al., 2015) it allows to identify hotspots of change in the land-system in a different way from LUC. South/Southeast Asia is the most extreme in SSP3 as food availability remains at the same level (India even experiences a deterioration) whereas it increases in all other regions. Moreover, food prices increase sharply. This implies that SSP3 assumptions such as limited international trade, slow yield improvements, and high population growth result in major threats to food security. Specifically in India, food security is also affected by low land availability which limits the possibility to expand agricultural land. This highlights the necessity for India to invest in yield improvement and to limit population growth. It also indicates the importance of land availability as a model parameter. Estimates of land availability are uncertain and vary substantially (Eitelberg et al., 2015): possible improvements could come from empirical data on soil quality to exclude areas unsuitable for cropland, or spatially explicit costs of conversion related to original land-use and accessibility. Next to that, the effects of land scarcity on agriculture and land-use change is uncertain (Lambin, 2012), and the way in which models handle these effects differs.

The set of scenarios presented in this paper provides high resolution gridded land-use data (Fig. 10, SI Fig. 4a-g). In IMAGE, the land-use allocation algorithm for cropland and pasture is based on a regional empirical multiple linear regression model fitting a selection of potential drivers of land-use change to current land use (Section 2.1), which is an improvement over the rule-based approach of previous IMAGE versions (Alcamo et al., 1998). This is similar to the CLUMondo model which uses a regional logistic regression model that combines a large selection of potential drivers with the current distribution of land systems (Van Asselen and Verburg, 2013). The disadvantage of this approach is that it is unknown whether future land-use expansion will follow the current land-use distribution patterns, due to changing drivers of LUC. A solution to this issue is fitting the model to historical data of land-use change, preferably based on satellite observations. The recently published land cover time series of the ESA climate change initiative provides data from 1992 to 2015 that might prove suitable for this purpose (Hollmann et al., 2013). Next to land-use expansion, abandonment of agricultural land is an important process in some scenarios (e.g. SSP1). In IMAGE-LandManagement abandonment takes place on locations with the lowest productivity which is consistent with historical land abandonment in Europe, for example in the Mediterranean regions of France. Specific biodiversity policies could however alter this process as productive agricultural land is converted for nature restoration, therefore necessitating a more advanced approach to land abandonment. Lastly, allocation in larger regions comprising countries with very different political and economic characteristics is important. For example, Western Africa covers both Nigeria and the Democratic Republic of the Congo where the former experiences high economic growth rates and the latter continuous to be affected by conflict. Multilevel modelling including national and gridded level variables could improve this (Neumann et al., 2011).

The results of the mitigation scenarios show that land use plays an important role in climate change mitigation. As GHG emissions were not reduced sufficiently in the recent past and are most likely not sufficiently reduced in the near future, and as not all emissions from the energy and the land system can be reduced to zero (e.g. $\mathrm{CH}_{4}$ and $\mathrm{N}_{2} \mathrm{O}$ emissions from agriculture) negative emissions through BECCS and afforestation are needed to achieve ambitious climate targets (Van Vuuren et al., 2013). Especially in $1.5^{\circ} \mathrm{C}$ scenarios very large increases in production of bioenergy are required already by 2050. A trade-off of land-based mitigation might be negative effects on food security: in Sub-Saharan Africa, the implementation of REDD causes a reduction in food availability and a sharp increase in food prices. Another trade-off is caused by large-scale expansion of bioenergy plantations in nonforest ecosystems which probably negatively affects biodiversity (Ten Brink et al., 2010). These effects indicate that land-based climate mitigation in developing regions might have severe consequences that are in conflict with the achievement of sustainable development goals (SDG) such as no poverty, zero hunger and life on land (UN G.A., 2015). Therefore, large-scale land-based mitigation will have to be accompanied by additional policies to reduce or avoid trade-offs, especially in the food system. In IMAGE, the effects of land-based mitigation on the land system could be underestimated as bioenergy and afforestation do not compete with agriculture. Other IAM models that participated in the development of the SSP scenarios show a stronger effect of climate policy on land use, which is most noticeable comparing SSP2 and SSP22.6 (SI Fig. 1b) in MESSAGE-GLOBIOM (Havlik et al., 2012), REMINDMAgPIE (Popp et al., 2011) and GCAM4 (Wise et al., 2014). It is likely that large-scale land-based mitigation will have consequences for various SDGs. Modelling these interactions and trade-offs is an important 
field of research for the IAM community.

By design, the SSP scenarios do not include impacts of climate change on the land system. Analyses show that climate change may have a substantial and predominantly negative effect on crop yields on a global scale, especially if $\mathrm{CO}_{2}$ fertilization is excluded (Rosenzweig et al., 2014; Asseng et al., 2013; Müller et al., 2015). The impact of $\mathrm{CO}_{2}$ fertilization is uncertain. On a regional scale however, climate change can have a beneficial effect on crop yields, typically on high latitudes. Climate impacts (negative and positive) will have a substantial impact on the agro-economic system (Nelson et al., 2014). The IMAGE 3.0 model framework couples the dynamic vegetation model LPJmL to the simple climate model MAGICC and the agro-economic model MAGNET making it very suitable to assess climate change impacts throughout the land system. For example, if the severe climate change impacts in the case of SSP3 are accounted for (about $4{ }^{\circ} \mathrm{C}$ warming in 2100), this would lead to reduced yields in South Asia and Sub-Saharan Africa and increasing yields in USA, Europe and Russia. As a consequence, the southern regions will be more dependent on food imports and food security will be worse. In other studies, we have estimated the impacts of climate change on the IMAGE SSP scenarios (JRC, 2017).

An important purpose of the RCP-SSP scenario framework is "to strengthen cooperation between integrated-assessment modellers, climate modellers, and vulnerability, impact and adaptation researchers" (Van Vuuren et al., 2012). Land use is a crucial interface between many of these research fields. The publication of this set of land-use scenarios aims to facilitate this cooperation. Various studies implementing the IMAGE SSP scenario are currently in progress. Biogeochemical and biogeophysical climate change effects in ambitious mitigation scenarios are disentangled using the Community Earth System Model (Hurrell et al., 2013). The scenarios are used to assess impacts on biodiversity with the GLOBIO model (Alkemade et al., 2009), and nitrogen and phosphorus cycles are investigated by implementing the scenarios in the Global Nutrient Model (GNM)(Beusen et al., 2015). Finally, the scenarios will be part of the Land-Use Harmonization (LUH2) project (Hurtt et al., 2011) which will provide input to the Coupled Model Intercomparison Project Phase 6 (CMIP6) (Eyring et al., 2016).

\section{Acknowledgements}

The authors would like to thank the researchers of other research groups involved in the SSPs as the development of theIMAGE scenarios greatly benefited from the constructive comments received throughout the process. Liesbeth de Waal and Rineke Oostenrijk are gratefully acknowledged for their technical support. The development of the IMAGE SSPs also benefited from the funding of the European Union's Seventh Framework ProgrammeFP7/2007-2013 under grant agreement $\mathrm{n}^{\circ}$ 603542 (LUC4C).

\section{References}

Alcamo, J., Leemans, R., Kreileman, E., 1998. Global Change Scenarios of the 21 St Century: Results from the IMAGE 2.1 Model.

Alexandratos, N., Bruinsma, J., 2012. World Agriculture Towards 2030/.

Alkemade, R., Van Oorschot, M., Miles, L., Nellemann, C., Bakkenes, M., Ten Brink, B., 2009. GLOBIO3: a framework to investigate options for reducing global terrestrial biodiversity loss. Ecosystems 12, 374-390.

Asseng, S., Ewert, F., Rosenzweig, C., Jones, J., Hatfield, J., Ruane, A., Boote, K. Thorburn, P., Rötter, R., Cammarano, D., 2013. Uncertainty in simulating wheat yields under climate change. Nat. Clim. Change 3, 827-832.

Beusen, A.H.W., Van Beek, L.P.H., Bouwman, A.F., Mogollón, J.M., Middelburg, J.J., 2015. Coupling global models for hydrology and nutrient loading to simulate nitrogen and phosphorus retention in surface water - description of IMAGE-GNM and analysis of performance. Geosci. Model Dev. 8, 4045-4067.

Billen, G., Lassaletta, L., Garnier, J., 2015. A vast range of opportunities for feeding the world in 2050: trade-off between diet, $\mathrm{N}$ contamination and international trade. Environ. Res. Lett. 10, 025001.

Bondeau, A., Smith, P.C., Zaehle, S., Schaphoff, S., Lucht, W., Cramer, W., Gerten, D., Lotze-Campen, H., Müller, C., Reichstein, M., Smith, B., 2007. Modelling the role of agriculture for the 20th century global terrestrial carbon balance. Global Change Biol. $13,679-706$.
Bouwman, A., Van Der Hoek, K., Eickhout, B., Soenario, I., 2005. Exploring changes in world ruminant production systems. Agric. Syst. 84, 121-153.

CBD, 2010. COP Decision X/2. Strategic Plan for Biodiversity 2011-2020 and the Aichi Biodiversity Targets.

Ciais, P., Sabine, C., Bala, G., Bopp, L., Brovkin, V., Canadell, J., Chhabra, A., Defries, R., Galloway, J., Heimann, M., 2014. Carbon and Other Biogeochemical Cycles. Climate Change 2013: The Physical Science Basis. Contribution of Working Group I to the Fifth Assessment Report of the Intergovernmental Panel on Climate Change. Cambridge University Press.

Daioglou, V., Van Ruijven, B.J., Van Vuuren, D.P., 2012. Model projections for household energy use in developing countries. Energy 37, 601-615.

Daioglou, V., 2016. The Role of Biomass in Climate Change Mitigation: Assessing the Long-term Dynamics of Bioenergy and Biochemicals in the Land and Energy Systems.

Dellink, R., Chateau, J., Lanzi, E., Magné, B., 2017. Long-term economic growth projections in the Shared Socioeconomic Pathways. Global Environ. Change 42, 200-214.

Den Elzen, M.G., Lucas, P.L., Van Vuuren, D.P., 2008. Regional abatement action and costs under allocation schemes for emission allowances for achieving low CO2equivalent concentrations. Clim. Change 90, 243-268.

Eitelberg, D.A., Van Vliet, J., Verburg, P.H., 2015. A review of global potentially available cropland estimates and their consequences for model-based assessments. Global Change Biol. 21, 1236-1248.

Ellis, E.C., Ramankutty, N., 2008. Putting people in the map: anthropogenic biomes of the world. Front. Ecol. Environ. 6, 439-447.

Erb, K.H., Lauk, C., Kastner, T., Mayer, A., Theurl, M.C., Haberl, H., 2016. Exploring the biophysical option space for feeding the world without deforestation. Nat. Commun. 7.

Eyring, V., Bony, S., Meehl, G.A., Senior, C.A., Stevens, B., Stouffer, R.J., Taylor, K.E., 2016. Overview of the coupled model intercomparison project phase 6 (CMIP6) experimental design and organization. Geosci. Model Dev. 9, 1937-1958.

FAO, 1996. Rome Declaration on World Food Security and World Food Summit Plan of Action.

FAO, 2015. forest resource assessment was published by FAO (Food and Agricultural Organization of the United Nations(FAO)) and accessed online through. http://www. fao.org/3/a-i4808e.pdf.

FAOSTAT, 2013. Food and Agricultural Organization of the United Nations. [Online]. Available: www.fao.org/faostat (Accessed)

Fischer, G., Nachtergaele, F., Prieler, S., Van Velthuizen, H., Verelst, L., Wiberg, D., 2008. Global Agro-ecological Zones Assessment for Agriculture (GAEZ 2008). IIASA, Laxenburg, Austria and FAO, Rome, Italy, pp. 10.

Fischer, R., Byerlee, D., Edmeades, G., 2014. Crop Yields and Global Food Security. ACIAR, Canberra, ACT.

Foley, J.A., Defries, R., Asner, G.P., Barford, C., Bonan, G., Carpenter, S.R., Chapin, F.S., Coe, M.T., Daily, G.C., Gibbs, H.K., Helkowski, J.H., Holloway, T., Howard, E.A., Kucharik, C.J., Monfreda, C., Patz, J.A., Prentice, I.C., Ramankutty, N., Snyder, P.K., 2005. Global consequences of land use. Science 309, 570-574.

Foley, J.A., Ramankutty, N., Brauman, K.A., Cassidy, E.S., Gerber, J.S., Johnston, M., Mueller, N.D., O'connell, C., Ray, D.K., West, P.C., Balzer, C., Bennett, E.M., Carpenter, S.R., Hill, J., Monfreda, C., Polasky, S., Rockstrom, J., Sheehan, J., Siebert, S., Tilman, D., Zaks, D.P., 2011. Solutions for a cultivated planet. Nature 478, 337-342.

Fritz, S., See, L., Van Der Velde, M., Nalepa, R.A., Perger, C., Schill, C., Mccallum, I., Schepaschenko, D., Kraxner, C.A.I.X., Ortner, S., Hazarika, R., Cipriani, A., Di Bella, C., Rabia, A.H., Garcia, A., Vakolyuk, M., Singha, K., Beget, M.E., Erasmi, S., Albrecht, F., Shaw, B., Obersteiner, M., 2013. Downgrading recent estimates of land available for biofuel production. Environ. Sci. Technol. 47, 1688-1694.

Gernaat, D.E.H.J., Calvin, K., Lucas, P.L., Luderer, G., Otto, S.A.C., Rao, S., Strefler, J., Van Vuuren, D.P., 2015. Understanding the contribution of non-carbon dioxide gases in deep mitigation scenarios. Global Environ. Change 33, 142-153.

Grassini, P., Eskridge, K.M., Cassman, K.G., 2013. Distinguishing between yield advances and yield plateaus in historical crop production trends. Nat. Commun. 4.

Gustavsson, J., Cederberg, C., Sonesson, U., Van Otterdijk, R., Meybeck, A., 2011. Global Food Losses and Food Waste. Food and Agriculture Organization of the United Nations, Rom.

Hasegawa, T., Fujimori, S., Takahashi, K., Masui, T., 2015. Scenarios for the risk of hunger in the twenty-first century using Shared Socioeconomic Pathways. Environ. Res. Lett. 10, 014010.

Havlik, P., Valin, H., Mosnier, A., Obersteiner, M., Baker, J.S., Herrero, M., Rufino, M.C., Schmid, E., 2012. Crop productivity and the global livestock sector: implications for land use change and greenhouse gas emissions. Am. J. Agric. Econ. 95, 442-448.

Hertel, T.W., 1997. Global Trade Analysis: Modeling and Applications. Cambridge University Press.

Hollmann, R., Merchant, C.J., Saunders, R., Downy, C., Buchwitz, M., Cazenave, A., Chuvieco, E., Defourny, P., DE Leeuw, G., Forsberg, R., 2013. The ESA climate change initiative: satellite data records for essential climate variables. Bull. Am. Meteorol. Soc. 94, 1541-1552.

Hoogwijk, M., Faaij, A., Van Den Broek, R., Berndes, G., Gielen, D., Turkenburg, W., 2003. Exploration of the ranges of the global potential of biomass for energy. Biomass Bioenergy 25, 119-133.

Hurrell, J.W., Holland, M.M., Gent, P.R., Ghan, S., Kay, J.E., Kushner, P.J., Lamarque, J. F., Large, W.G., Lawrence, D., Lindsay, K., 2013. The community earth system model: a framework for collaborative research. Bull. Am. Meteorol. Soc. 94, 1339-1360.

Hurtt, G.C., Chini, L.P., Frolking, S., Betts, R.A., Feddema, J., Fischer, G., Fisk, J.P., Hibbard, K., Houghton, R.A., Janetos, A., Jones, C.D., Kindermann, G., Kinoshita, T., Klein Goldewijk, K., Riahi, K., Shevliakova, E., Smith, S., Stehfest, E., Thomson, A., Thornton, P., Van Vuuren, D.P., Wang, Y.P., 2011. Harmonization of land-use scenarios for the period 1500-2100: 600 years of global gridded annual land-use 
transitions, wood harvest, and resulting secondary lands. Clim. Change 109, 117-161.

IUCN, U.-W., 2015. The World Database on Protected Areas. Cambridge, UK (Online].Available: www.protectedplanet.net [Accessed).

JRC, 2017. In: Meijl, H.V., Havlik, P., Lotze-Campen, H., Stehfest, E., Witzke, P., Domínguez, I.P., Bodirsky, B., Dijk, M.V., Doelman, J., Fellmann, T., Humpenoeder, F., Levin-Koopman, J., Christoph Mueller Popp, A., Tabeau, A., Valin, H. (Eds.), Challenges of Global Agriculture in a Climate Change Context by 2050 (AgCLIM50). JRC Science for Policy Report. Publications Office of the European Union, Luxembourg.

JRC/PBL, 2012. Emission Database for Global Atmospheric Research (EDGAR). Release Version 2 4.2, ft2010 ed. .

Jiang, L., O'neill, B.C., 2017. Global urbanization projections for the shared socioeconomic pathways. Global Environ. Change 42, 193-199.

Jones, C., Ciais, P., Davis, S., Friedlingstein, P., Gasser, T., Peters, G., Rogelj, J., Van Vuuren, D., Canadell, J., Cowie, A., 2016. Simulating the Earth system response to negative emissions. Environ. Res. Lett. 11, 095012.

KC, S., Lutz, W., 2017. The human core of the shared socioeconomic pathways: population scenarios by age, sex and level of education for all countries to 2100. Global Environ. Change 42, 181-192.

Kindermann, G., Obersteiner, M., Sohngen, B., Sathaye, J., Andrasko, K., Rametsteiner, E., Schlamadinger, B., Wunder, S., Beach, R., 2008. Global cost estimates of reducing carbon emissions through avoided deforestation. Proc. Natl. Acad. Sci. U. S. A. 105, 10302-10307.

Klein Goldewijk, K., Beusen, A., Janssen, P., 2010. Long-term dynamic modeling of global population and built-up area in a spatially explicit way: HYDE 3.1. Holocene 20, 565-573.

Klein Goldewijk, K., Beusen, A., Van Drecht, G., Vos, D.E.M., 2011. The HYDE 3. 1 spatially explicit database of human-induced global land-use change over the past 12,000 years. Global Ecol. Biogeogr. 20, 73-86.

Lambin, E.F., Meyfroidt, P., 2011. Global land use change, economic globalization, and the looming land scarcity. Proc. Natl. Acad. Sci. U. S. A. 108, 3465-3472.

Lambin, E.F., 2012. Global land availability: malthus versus ricardo. Global Food Secur. $1,83-87$.

Lassaletta, L., Billen, G., Grizzetti, B., Anglade, J., Garnier, J., 2014. 50 year trends in nitrogen use efficiency of world cropping systems: the relationship between yield and nitrogen input to cropland. Environ. Res. Lett. 9, 105011.

Lehner, B., Döll, P., 2004. Development and validation of a global database of lakes: reservoirs and wetlands. J. Hydrol. 296, 1-22.

Lucas, P.L., Van Vuuren, D.P., Olivier, J.G.J., Den Elzen, M.G.J., 2007. Long-term reduction potential of non-CO2 greenhouse gases. Environ. Sci. Policy 10, 85-103.

Müller, C., Elliott, J., Chryssanthacopoulos, J., Deryng, D., Folberth, C., Pugh, T.A.M., Schmid, E., 2015. Implications of climate mitigation for future agricultural produc tion. Environ. Res. Lett. 10, 125004.

Müller, C., Stehfest, E., Van Minnen, J.G., Strengers, B., Von Bloh, W., Beusen, A.H.W. Schaphoff, S., Kram, T., Lucht, W., 2016. Drivers and patterns of land biosphere carbon balance reversal. Environ. Res. Lett. 11, 044002.

Mandryk, M., Doelman, J.C., Stehfest, E., 2015. Assessment of Global Land Availability. FOODSECURE Technical Working Paper No. 7.

Meinshausen, M., Raper, S.C.B., Wigley, T.M.L., 2011. Emulating coupled atmosphereocean and carbon cycle models with a simpler model, MAGICC6-part 1: model description and calibration. Atmos. Chem. Phys. 11, 1417-1456.

Molden, D., 2007. Water for Food. Water for Life. A Comprehensive Assessment of Water Management in Agriculture. International Water Management Institute (IWMI) and FAO.

Mueller, N.D., Gerber, J.S., Johnston, M., Ray, D.K., Ramankutty, N., Foley, J.A., 2012. Closing yield gaps through nutrient and water management. Nature 490, 254-257.

Nelson, G.C., Valin, H., Sands, R.D., Havlik, P., Ahammad, H., Deryng, D., Elliott, J., Fujimori, S., Hasegawa, T., Heyhoe, E., Kyle, P., Von Lampe, M., Lotze-Campen, H., Mason D'croz, D., Van Meijl, H., Van Der Mensbrugghe, D., Muller, C., Popp, A., Robertson, R., Robinson, S., Schmid, E., Schmitz, C., Tabeaua, A., Willenbockel, D., 2014. Climate change effects on agriculture: economic responses to biophysical shocks. Proc. Natl. Acad. Sci. U. S. A. 111, 3274-3279.

Nelson, A., 2008. Travel Time to Major Cities: A Global Map of Accessibility. Global Environment Monitoring Unit - Joint Research Centre of the European Commission., Ispra, Italy.

Neumann, K., Verburg, P.H., Stehfest, E., Müller, C., 2010. The yield gap of global grain production: a spatial analysis. Agric. Syst. 103, 316-326.

Neumann, K., Stehfest, E., Verburg, P.H., Siebert, S., Müller, C., Veldkamp, T., 2011. Exploring global irrigation patterns: a multilevel modelling approach. Agric. Syst. 104, 703-713.

O’Neill, B.C., Kriegler, E., Ebi, K.L., Kemp-Benedict, E., Riahi, K., Rothman, D.S., Van Ruijven, B.J., Van Vuuren, D.P., Birkmann, J., Kok, K., 2017. The roads ahead: narratives for shared socioeconomic pathways describing world futures in the 21 st century. Global Environ. Change 42, 169-180.

O'neill, B.C., Kriegler, E., Ebi, K.L., Kemp-Benedict, E., Riahi, K., Rothman, D.S., Van Ruijven, B.J., Van Vuuren, D.P., Birkmann, J., Kok, K., Levy, M., Solecki, W., 2015. The roads ahead: narratives for shared socioeconomic pathways describing world futures in the 21 st century. Global Environ. Change.

Popp, A., Dietrich, J.P., Lotze-Campen, H., Klein, D., Bauer, N., Krause, M., Beringer, T., Gerten, D., Edenhofer, O., 2011. The economic potential of bioenergy for climate change mitigation with special attention given to implications for the land system. Environ. Res. Lett. 6, 034017.

Popp, A., Rose, S.K., Calvin, K., Van Vuuren, D.P., Dietrich, J.P., Wise, M., Stehfest, E., Humpenöder, F., Kyle, P., Van Vliet, J., Bauer, N., Lotze-Campen, H., Klein, D., Kriegler, E., 2013. Land-use transition for bioenergy and climate stabilization: model comparison of drivers: impacts and interactions with other land use based mitigation options. Clim. Change 123, 495-509.

Popp, A., Calvin, K., Fujimori, S., Havlik, P., Humpenöder, F., Stehfest, E., Bodirsky, B.L., Dietrich, J.P., Doelman, J.C., Gusti, M., 2016. Land-use futures in the shared socioeconomic pathways. Global Environ. Change.

Popp, A., Calvin, K., Fujimori, S., Havlik, P., Humpenöder, F., Stehfest, E., Bodirsky, B.L., Dietrich, J.P., Doelmann, J.C., Gusti, M., 2017. Land-use futures in the shared socioeconomic pathways. Global Environ. Change 42, 331-345.

Quéré, C.L., Andrew, R.M., Canadell, J.G., Sitch, S., Korsbakken, J.I., Peters, G.P., Manning, A.C., Boden, T.A., Tans, P.P., Houghton, R.A., 2016. Global carbon budget 2016. Earth Syst. Sci. Data 8, 605-649.

Riahi, K., Van Vuuren, D.P., Kriegler, E., Edmonds, J., O'neill, B.C., Fujimori, S., Bauer, N., Calvin, K., Dellink, R., Fricko, O., 2017. The shared socioeconomic pathways and their energy, land use, and greenhouse gas emissions implications: an overview. Global Environ. Change 42, 153-168.

Rosenzweig, C., Elliott, J., Deryng, D., Ruane, A.C., Muller, C., Arneth, A., Boote, K.J., Folberth, C., Glotter, M., Khabarov, N., Neumann, K., Piontek, F., Pugh, T.A., Schmid, E., Stehfest, E., Yang, H., Jones, J.W., 2014. Assessing agricultural risks of climate change in the 21 st century in a global gridded crop model intercomparison. Proc. Natl. Acad. Sci. U. S. A. 111, 3268-3273.

Ruesch, A., Gibbs, H.K., 2008. New IPCC Tier-1 Global Biomass Carbon Map for the Year 2000. Oak Ridge National Laboratory, Oak Ridge, Tennessee(Online] Available: http://cdiac.ornl.gov/epubs/ndp/global_carbon/carbon_documentation.html [Accessed).

Schmitz, C., Van Meijl, H., Kyle, P., Nelson, G.C., Fujimori, S., Gurgel, A., Havlik, P., Heyhoe, E., D'croz, D.M., Popp, A., Sands, R., Tabeau, A., Van Der Mensbrugghe, D., Von Lampe, M., Wise, M., Blanc, E., Hasegawa, T., Kavallari, A., Valin, H., 2014. Land-use change trajectories up to 2050: insights from a global agro-economic model comparison. Agric. Econ. 45, 69-84.

Sitch, S., Smith, B., Prentice, I.C., Arneth, A., Bondeau, A., Cramer, W., Kaplan, J., Levis, S., Lucht, W., Sykes, M.T., 2003. Evaluation of ecosystem dynamics, plant geography and terrestrial carbon cycling in the LP: J dynamic global vegetation model. Global Change Biol. 9, 161-185.

Smith, P., Gregory, P.J., Van Vuuren, D., Obersteiner, M., Havlik, P., Rounsevell, M., Woods, J., Stehfest, E., Bellarby, J., 2010. Competition for land. Philos. Trans. R Soc. Lond. B Biol. Sci. 365, 2941-2957.

Smith, P., 2013. Chapter 11: Agriculture, Forestry and Other Land Use (AFOLU). IPCC WGIII AR5.

Solomon, S., 2007. Climate Change 2007-the Physical Science Basis: Working Group I Contribution to the Fourth Assessment Report of the IPCC. Cambridge University Press.

Stehfest, E., Bouwman, L., Van Vuuren, D.P., Den Elzen, M.G.J., Eickhout, B., Kabat, P., 2009. Climate benefits of changing diet. Clim. Change 95, 83-102.

Stehfest, E., Van Vuuren, D., Kram, T., Bouwman, L., Alkemade, R., Bakkenes, M. Biemans, H., Bouwman, A., Den Elzen, M., Janse, J., Lucas, P., Van Minnen, J., Müller, C., Prins, A., 2014. Integrated Assessment of Global Environmental Change with IMAGE 3.0. Model Description and Policy Applications. Netherlands Environmental Assessment Agency (The Hague).

Strengers, B.J., Leemans, R., Eickhout, B., DE Vries, B., Bouwman, L., 2004. The land-use projections and resulting emissions in the IPCC SRES scenarios as simulated by the IMAGE 2.2 model. GeoJournal 61, 12.

Ten Brink, B., Van Der Esch, S., Kram, T., Van Oorschot, M., Arets, E., 2010. Rethinking Global Biodiversity Strategies: Exploring Structural Changes in Production and Consumption to Reduce Biodiversity Loss. Netherlands Environmental Assessment Agency.

Tokarick, S., 2006. Does Import Protection Discourage Exports?.

UN G.A, 2015. Transforming Our World: The 2030 Agenda for Sustainable Development. (A/RES/70/1, 21 October).

UNFCC, 2015. In: UNFCCC (Ed.), Unfccc 2015. Paris Agreement, Paris.

Van Asselen, S., Verburg, P.H., 2013. Land cover change or land-use intensification: simulating land system change with a global-scale land change model. Global Change Biol. 19, 3648-3667.

Van Ittersum, M.K., Cassman, K.G., Grassini, P., Wolf, J., Tittonell, P., Hochman, Z., 2013. Yield gap analysis with local to global relevance-a review. Field Crops Res. 143, 4-17.

Van Ittersum, M.K., Van Bussel, L.G., Wolf, J., Grassini, P., Van Wart, J., Guilpart, N., Claessens, L., DE Groot, H., Wiebe, K., Mason-D'croz, D., 2016. Can sub-Saharan Africa feed itself? Proc. Natl. Acad. Sci. 113, 14964-14969.

Van Meijl, H., Van Rheenen, T., Tabeau, A., Eickhout, B., 2006. The impact of different policy environments on agricultural land use in Europe. Agric. Ecosyst. Environ. 114, 21-38.

Van Vuuren, D.P., Edmonds, J., Kainuma, M., Riahi, K., Thomson, A., Hibbard, K., Hurtt, G.C., Kram, T., Krey, V., Lamarque, J.-F., Masui, T., Meinshausen, M., Nakicenovic, N., Smith, S.J., Rose, S.K., 2011. The representative concentration pathways: an overview. Clim. Change 109, 5-31.

Van Vuuren, D.P., Riahi, K., Moss, R., Edmonds, J., Thomson, A., Nakicenovic, N., Kram, T., Berkhout, F., Swart, R., Janetos, A., Rose, S.K., Arnell, N., 2012. A proposal for a new scenario framework to support research and assessment in different climate research communities. Global Environ. Change 22, 21-35.

Van Vuuren, D.P., Deetman, S., Van Vliet, J., Van Den Berg, M., Van Ruijven, B.J., Koelbl, B., 2013. The role of negative CO2 emissions for reaching $2^{\circ} \mathrm{C}$-insights from integrated assessment modelling. Clim. Change 118, 15-27.

Van Vuuren, D.P., Stehfest, E., Gernaat, D.E., Doelman, J.C., Van Den Berg, M., Harmsen, M., De Boer, H.S., Bouwman, L.F., Daioglou, V., Edelenbosch, O.Y., 2017. Energy, land-use and greenhouse gas emissions trajectories under a green growth paradigm. Global Environ. Change 42, 237-250. 
Van Vuuren, D.P., 2007. Energy Systems and Climate Policy-long-term Scenarios for an Uncertain Future.

Verburg, P.H., Van De Steeg, J., Veldkamp, A., Willemen, L., 2009. From land cover change to land function dynamics: a major challenge to improve land characterization. J. Environ. Manage. 90, 1327-1335.

Winsemius, H.C., Van Beek, L.P.H., Jongman, B., Ward, P.J., Bouwman, A., 2013. A framework for global river flood risk assessments. Hydrol. Earth Syst. Sci. 17,
1871-1892.

Wise, M., Calvin, K., Kyle, P., Luckow, P., Edmonds, J., 2014. Economic and physical modeling of land use in GCAM 3.0 and an application to agricultural productivity, land, and terrestrial carbon. Climate Change Econ. 5, 1450003.

Woltjer, G.B., Kuiper, M.H., 2014. The MAGNET Model: Module Description. LEI Wageningen UR, Wageningen. 